\title{
A chronological review of advances in solar assisted heat pump technology in $21^{\text {st }}$ century
}

Badiei, A.* , Golizadeh Akhlaghi, Y., Zhao, X., Shittu, S., Xiao, X., Li, J., Fan, Y., Li, G.

Centre for Sustainable Energy Technologies, Energy and Environment Institute, University of Hull, Hull, HU6 7RX, UK

*Corresponding author details: A.Badiei@hull.ac.uk; Tel: 01482463611

\begin{abstract}
This paper presents a comprehensive review on developments and advances of Solar Assisted Heat Pump technology reported in $21^{\text {st }}$ century. Combination of thermal and photovoltaic solar collectors with heat pumps has been widely used in recent decades for simultaneous heat, hot water and power generation for a broad range of applications, from providing domestic and commercial buildings with heat and power to manufacturing and agricultural applications. This review critically analyses the research reported in past two decades with particular attention to the works with substantial importance for future development of the technology. Four distinctive investigation periods were considered and key developments and dominant technologies at each period were reported. The main novelties and breakthroughs in solar assisted heat pump technology, as identified by this review, are: (1) The ban on R-12 refrigerant which lead to dominance of R-134A refrigerant for a wide range of systems and applications, (2) Increasing interest in Solar-assisted Ground Source Heat Pumps following the technological advances that made the utilization of such systems cost effective, (3) Advances in numerical analysis methods and use of Artificial Intelligence applications in investigating performance and effectiveness of various systems, and (4) Integrating the Photovoltaic/Thermal collectors with heat pumps for simultaneous heat and power generation resulting in improved performance and reliable operation of systems under severe operating conditions.
\end{abstract}

\section{Highlights}

- Four distinctive investigation periods from 2000 to 2020 are considered

- Key developments and prevailing breakthroughs at each period are presented

- Advantages and shortcomings of each study are discussed

- Different types of SAHPs, applications, and performances are investigated

Keywords: Heat Pump; Solar Assisted; Direct Expansion; Experiment; Solar Energy; Photovoltaic; Thermal.

[Review article; word count: 9900] 


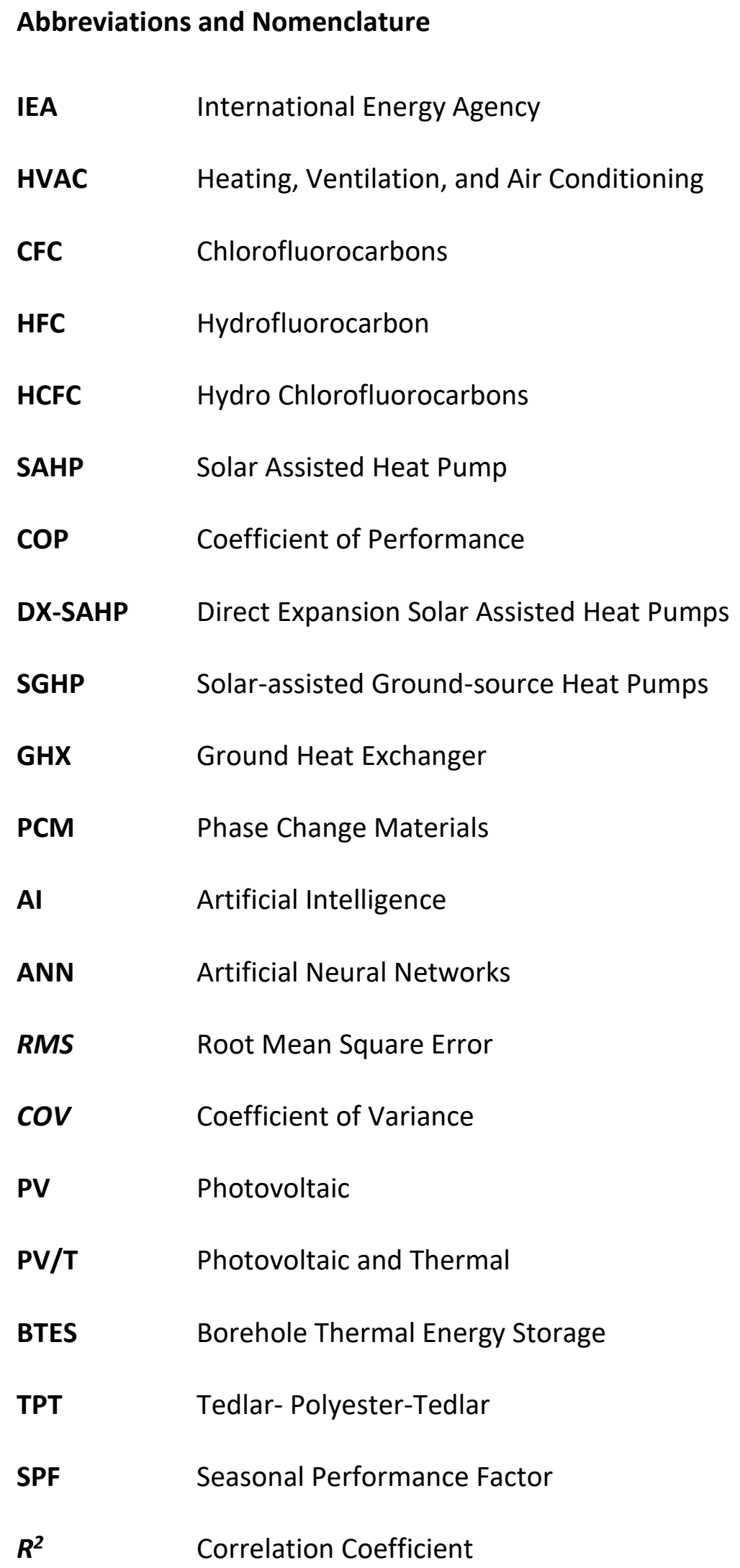




\section{Introduction}

The increasing worldwide energy consumption, especially in past decades, has raised the world-wide concern over security of supply as the existing energy resources are exhausting. The overwhelming evidences gathered by International Energy Agency (IEA) have revealed the devastating impact such rapid growth in energy consumption has on the environment. The latest IEA report, World Energy Outlook [1] indicates that the energy related $\mathrm{CO}_{2}$ emissions has raised by more than $37 \%$ in 2018 compared to 1990 levels (from $20.5 \mathrm{Gt} \mathrm{CO}_{2}$ in 1990 to $33 \mathrm{Gt} \mathrm{CO}_{2}$ in 2018) and if the energy demand keep rising at the current rate there will be a further $21 \%$ increase in energy related $\mathrm{CO}_{2}$ emissions by 2040 ( $42 \mathrm{Gt} \mathrm{CO}$ ). These shocking figures have been accompanied by an analysis of a best case scenario aligned with Paris Agreement, namely the Sustainable Development Scenario, where if implemented, would only result in keeping the energy related $\mathrm{CO}_{2}$ emissions at 2018 levels by 2040 [1]. One of the key contributors to the increasing world-wide energy consumption is the service sector which covers all types of buildings with a wide range of HVAC system [2], [3]. The global energy consumption of service sector has increased by 295 Mtoe in 2018 compared to 2000 levels and with this trend the sector would consume a further 323 Mtoe by 2040. The sector has also showed the least reduction potential in energy consumption under the Sustainable Development Scenario, compared to Industry, Residential and Transport sectors [1].

The growing energy use by HVAC systems are particularly significant in developed countries. In the USA, HVAC energy use accounts for up to $50 \%$ of building energy consumption while in china the HVAC energy use is between $50-70 \%$ of the total energy consumed in buildings [4]. With current global warming rate and the climate change, it is anticipated that the energy consumption associated with air-conditioning will be the key factor in determining HVAC energy consumption level in coming decades. The importance of air-conditioning has already been noticed, particularly in hot climates like Middle East and South-East Asia where it is the only applicable function of HVAC systems. Issac and Vuuren [5] estimated that energy demand associated with air-conditioning will rise rapidly in $21^{\text {st }}$ century reaching a peak of 4000 TWh in 2050 and more than 10,000 TWh by 2100. Such dramatic rise is anticipated to be particularly due to the rise in energy requirements of space cooling in commercial buildings as a result of climate warming [6]. There are other studies which have 
predicted a similar rise in energy demand of air-conditioning under future weather conditions of USA [7], Switzerland [8], and Australia [9]. To deal with the high energy consumption levels associated with the service sector and to improve its poor performance under future scenarios, the focus has been shifted toward development of advanced, hybrid, efficient and low-energy HVAC solutions in recent years.

One of the key technologies developed and evolved extensively in past decade to overcome the challenges associated with high consumption of HVAC units and resultant carbon emissions is Heat Pump technology. Heat Pumps, in nature, are refrigerators that transfer energy from the source with lower temperature to the source with higher temperature using the external energy input (electricity) and energy carrying medium (refrigerant). Heat Pumps are identified as the only known process that utilises the waste heat from the building and from the environment to produce useful heating and cooling energy [10]. With increasing fuel price and global warming gaining international attention, the interest in Heat Pumps as efficient and effective means of energy conversion has increased. A schematic diagram of a typical heat pump cycle is presented in Figure 1.

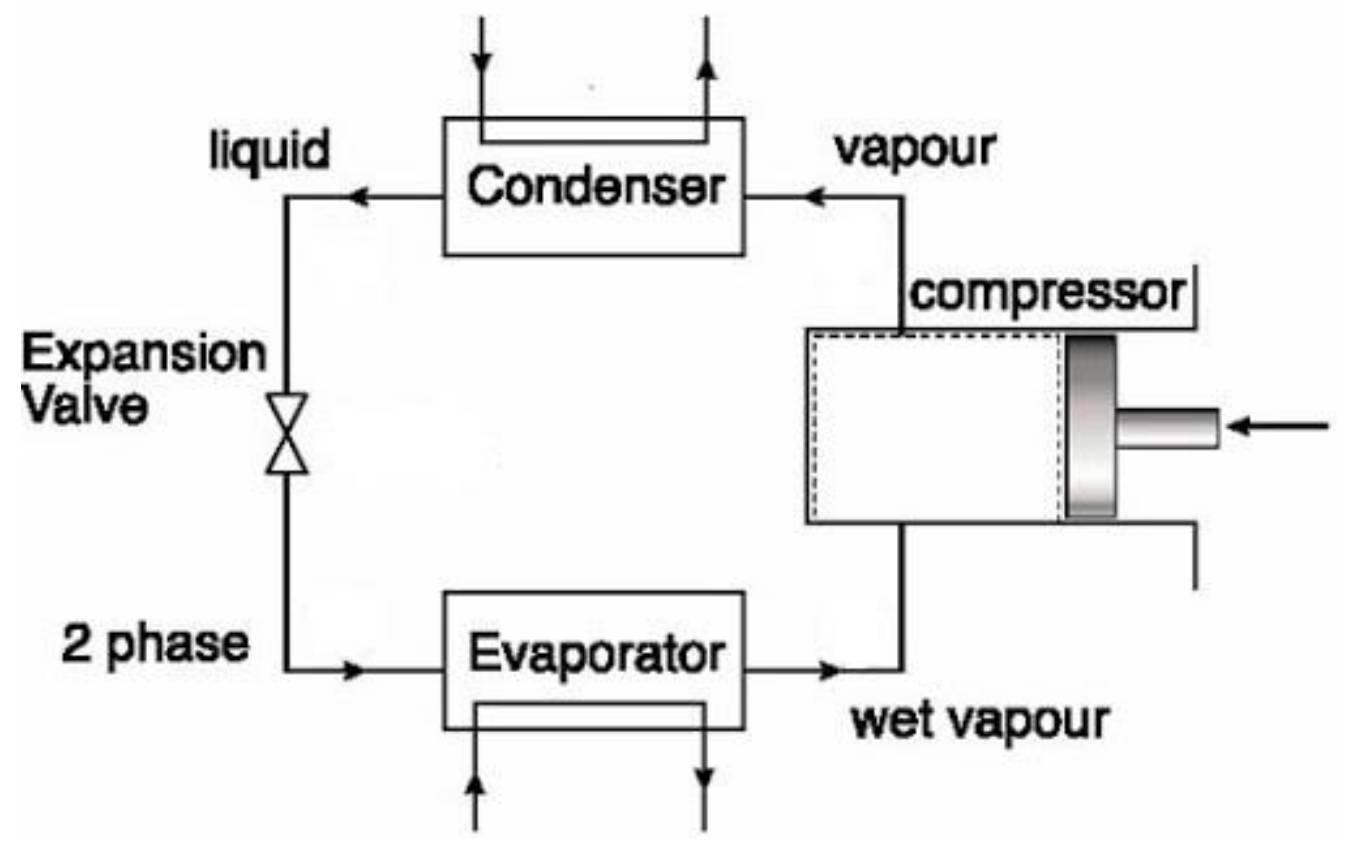

Figure 1 Representation of a simple heat pump cycle

As illustrated in Figure 1, the refrigerant vapour with low pressure and temperature enters compressor increasing vapour's pressure and temperature, which then enters the 
condenser (heat exchanger) and cools down to its saturation temperature by ambient air or water. In the condenser the vapour turns into liquid rejecting heat to the surrounding medium (air or water). This liquid refrigerant with high pressure and temperature then passes through an expansion valve becoming a low pressure and temperature liquid. The liquid then enters the evaporator to be vaporised and then cycle repeats again. Depending on the design and application of heat pumps, the refrigerants can be chosen from a range of CFCs and hydro chlorofluorocarbons (HCFCs) which are analysed in detail in Section 2.

To further improve energy performance and to reduce electricity consumption, carbon emissions, and operational cost of heat pumps, an integration of solar energy and heat pump technology has been introduced and investigated in recent decades. The resultant technology is called Solar Assisted Heat Pump (SAHP) which is an innovative way of reducing or even eliminating the primary energy source (coal, gas, and electricity) by employing renewable energy sources to reduce carbon emissions. The SAHP technology is capable of converting and transporting the solar heat to working fluid with capacity to store heat. By modifying the system configuration, reduced cost and improved efficiencies can be achieved, resulting in increasing interest in hybrid systems with a variety of system configurations suitable various climates.

With such demonstrated advantages, the SAHP technology has proved to have the potential to dominate the heating, cooling and power generation market in near future. With numerous researchers working on different aspects of the technology in recent years, there is a major need to discover which previous efforts provide best practice examples for further development of the technology. Hence, this paper investigates all the relevant research carried out on SAHP technology with particular attention to the works with substantial importance for future development of the technology. Compared to earlier reviews of the technology [120]-[123], the review offered in this paper is unique and novel as it only considers the research carried out in $21^{\text {st }}$ century, eliminating all the works which cannot be utilised or re-produced at the current time or in the future due to (1) inefficient performances, (2) ineffective approaches, and (3) recent changes in the rules and regulations limiting the use of materials and substances introduced by older research. Hence, without populating the review with non-related previous efforts, this review focuses 
on reporting the lessons learnt from relevant previous research and establishes the current and future trends leading to exceptional advances in the SAHP technology.

The advances of SAHP developments in $21^{\text {st }}$ century, up to the year 2020 , is investigated by dividing the century into four quarters:

\section{First quarter: $\mathbf{2 0 0 0}$ to $\mathbf{2 0 0 5}$}

\subsection{Dominance of $R-134 A$ refrigerant}

The SAHP developments in first quarter of $21^{\text {st }}$ century was extensively affected by the Montreal Protocol on Substances that Deplete the Ozone Layer [12] which banned the use of R-12 refrigerant in 1987. The Montreal Protocol is counted as the first environmental treaty to achieve universal endorsement by all countries which lead to other initiatives like the Kyoto Protocol ${ }^{1}$ which was adopted in 1997 and entered into force in 2005 [13]; and Paris Agreement ${ }^{2}$ which was signed in 2016 by $195^{3}$ countries [14]. The aim of Montreal Protocol is to protect stratospheric ozone layer by reducing production and consumption of ozone-depleting substances such as chlorofluorocarbons (CFCs) based refrigerants [15]. Hence, the majority of studies in the years leading to $21^{\text {st }}$ century, which used banned refrigerants like R-12 [16]-[20], are of a very limited value, thus this review only involves the ongoing advances in SAHPs research with still in-use refrigerants.

The elimination of R-12 as the most common refrigerant used at the time increased the interest in other Hydrofluorocarbon (HFC) refrigerants and their suitability for various applications. A study by Chata et al. [21] investigated new refrigerants which were commercially available at early 2000 s as the main working fluid and refrigerant for SAHP systems. The analysed HFC refrigerants were: R-134A. R-404A, R-410A, and R-407C to identify the best suited refrigerant for SAHP application and characterise the extent of resultant thermal performance degradation in comparison to R-12 and R-22 (another ozone-

\footnotetext{
${ }^{1}$ The Kyoto Protocol set binding emission reduction targets for 36 of the largest Green House Gas (GHG) emitting industrialized countries. These targets added up to a $5 \%$ reduction compared to $1990 \mathrm{GHG}$ emission levels to be achieved in the first commitment period (2008-2012)[13].

2 The Paris Agreement was aimed at keeping the temperature rise in $21^{\text {st }}$ century under 2 degrees Celsius above pre-industrial levels [14].

${ }^{3}$ The number of participating countries in Paris Agreement dropped to 194 on June 1, 2017 when the United States of America (USA) announced its withdrawal from the pact.
} 
depleting substance which was banned later) refrigerants. Table 1 summarises the key characteristics of the investigated HFC refrigerants and their main areas of application.

Table 1 Refrigerants, forming chemical components, corresponding compositions and key areas of application (partially re-created from [21])

\begin{tabular}{|c|c|c|c|}
\hline Refrigerants & Chemical components & Composition & The main areas of application \\
\hline $\mathrm{R}-12$ & Dichlorodifluoromethan & $100 \%$ & Banned \\
\hline R-22 & Monochlorodifluoromethan & $100 \%$ & Banned \\
\hline R-134A & 1,1,1,2-tetrafluoroethan & $100 \%$ & $\begin{array}{l}\text { Home appliances; commercial and } \\
\text { transport refrigeration; automotive air } \\
\text { conditioning }\end{array}$ \\
\hline$R-404 A$ & $R-125-R-143 A-R-134 A$ & $44 \%-52 \%-4 \%$ & Commercial refrigeration \\
\hline R-407C & $R-32-R-125-R-134 A$ & $23 \%-25 \%-52 \%$ & $\begin{array}{l}\text { Direct evaporation systems; domestic } \\
\text { and commercial air conditioning }\end{array}$ \\
\hline R-410A & $\mathrm{R}-32-\mathrm{R}-125$ & $50 \%-50 \%$ & Centrifugal and rotary compressors \\
\hline
\end{tabular}

As seen in Table 1, the R-404A, R-410A, and R-407C are zeotropic refrigerants meaning that they are formed by mixing two or more components with different boiling temperatures. Hence these components will evaporate and condense at different temperature, offering an opportunity to develop purpose-built zeotropic refrigerant (by choosing the right composition) for specific applications. The two banned refrigerants ( $\mathrm{R}-12$ and $\mathrm{R}-22$ ) are also included in Table 1 as the performance of SAHP system using new refrigerants is compared to the performance of conventional SAHP employing R-12 and R-22. The results showed, SAHPs using R-12 and R-22 yielded the highest COP values at any given solar collector temperature compared to rest of the refrigerants, and R-134A had the best performance among the new refrigerants. All the mixture zeotropic refrigerant resulted in lower system performance by up to $20 \%$ compared to R-134A. Besides R-134A's very reliable and high performance values, the higher global warming potential of R-404A, high pressure operation requirements of $\mathrm{R}-410 \mathrm{~A}$, and higher price of $\mathrm{R}-407 \mathrm{C}$ were all among the reasons for $\mathrm{R}-134 \mathrm{~A}$ to become the prominent refrigerant to be used in SAHP systems (and generally heat pumps) in early years of $21^{\text {st }}$ century [21]-[26].

\subsection{Transfer to Direct Expansion Solar Assisted Heat Pumps (DX-SAHP)}


Another wide spreading trend which was observed in the SAHP research of early 2000s was the increasing interest in Direct Expansion Solar Assisted Heat Pumps (DX-SAHP) as opposed to the conventional ones. In the conventional SAHPs, the solar collectors and the heat pump used to operate as two separate units and then mix in a transitional heat exchanger loop to transfer the solar heat to the heat transfer medium used by heat pump. In the DXSAHPs, however, the solar collectors and the heat pump are integrated into a single unit and the refrigerant runs through solar collectors undergoing a phase change from liquid to gas due to solar heat input [25]-[27].

All the studies investigating DX-SAHPs have reported significant improvements in the performance of the system when compared to the conventional configuration. The main reason behind the performance improvement is the refrigerant circulation in solar collector which reduces the collector temperature closer to ambient temperature, and thus reducing the heat loss from collector. The performance of heat pump also improves with direct expansion configuration due to the increase in evaporator temperature which reflects as increased heat pump COP value [21]. With DX-SAHPs employing HFC refrigerants like R134A some of the key shortcomings and technical obstacles of conventional SAHPs are eliminated:

- The life of solar collector is increased considerably due to removal of water-based corrosions possibility,

- The freezing problem in severely low ambient temperatures is eliminated as the refrigerants running through collectors have very low freezing temperature (for instance $\mathrm{R}-134 \mathrm{~A}$ freezes at $-96.67^{\circ} \mathrm{C}$ at atmospheric pressure),

- The heat loss and performance reduction associated with use of an intermittent heat exchanger in conventional SAHPs is also eliminated in DX-SAHP configuration.

\subsection{Other key developments in the first quarter}

Having established the key development focuses in the first quarter of $21^{\text {st }}$ century (20002005), the rest of this section will introduce and critically investigate the substantial research carried out (and published) with particular attention to novel technical features and resultant improved performance parameters. 
In 2001, Hawlader et al. [22] was among the first to investigate a DX-SAHP system with R134A refrigerant and a variable speed compressor to match the collector/evaporator load with compressor capacity. Their study investigated the system through experiments and analytical modelling under Singapore weather conditions. The investigated system showed an average COP value of $4-9$ and solar collector efficiency of $40-70 \%$ for condenser tank water temperatures of $30-50^{\circ} \mathrm{C}$. While the study was one of the pioneers of DX-SAHP research with $\mathrm{R}-134 \mathrm{~A}$ refrigerant, the published work lacked clarity on the model validation, uncertainty analysis and on the extent of climate data used. Huang and Chyng [25] performed a similar investigation on experimental analysis and analytical modelling of a DXSAHP employing R-134A as refrigerant. Authors' focus was on the adjustment of expansion valve opening to achieve higher performance recording COP values of 2.5-3.7 for water temperatures of $25-60^{\circ} \mathrm{C}$. The investigated system was capable of operating at evaporative temperatures of lower than ambient temperature and the analytical modelling results found to fit the experimental data.

In 2002, Badescu performed two analytical modelling studies [28], [29] on a DX-SAHP using R-114 refrigerant. The choice of refrigerant was unconventional in these studies as commercial availability and performance characteristics of R-114 wasn't well developed back at the time. However, since both studies only covered analytical investigation of the system, the feasibility of using R-114 in real life operation of a DX-SAHP wasn't considered. Both studies focused on first and second law analysis of the SAHP system coupled with a thermal storage unit, and electrical energy savings of up to $50 \%$ was recorded. In 2003 , Hawlader et al. [30] investigated a conventional SAHP system which treated solar collectors and heat pump as two separate units, former employing an air loop and later a refrigerant loop, joining together in a heat exchanger tank to provide heat and hot water. The heat output was used mainly for drying food grains through a blower and dryer unit. Similar to authors' earlier work, the system used a variable speed compressor to match the solar collector load and demand side requirements. The new system also employed a dehumidifier and auxiliary heating system to account for the humidity requirements of the food grains drying industries. The overall COP values from experiments was 5.0, whereas the simulations from the validated analytical model yielded a higher COP value of 7.0. Another study by Kuang et al. [31] studied a DX-SAHP incorporating a water source heat pump, a 
water-based solar collector loop, and a heat exchanger unit incorporating an auxiliary heater. Due to low operating temperature of the system a record solar collector efficiency of $67.2 \%$ for the time of study was recorded with COP values reaching 2.6. Chyng et al. [23] investigated a DX-SAHP water heater system with R-134A refrigerant under Taipei weather conditions achieving COP values of 1.7 to 2.5 by analytical modelling and experiments. The simulation work on this system assumed a quasi-steady state process for all components of the DX-SAHP water heater system. Although no evidence was provided on possible implications and resultant uncertainties of such assumption, the authors report on a good agreement of simulation results with experiments.

In 2004, $\mathrm{Bi}$ et al. [32] conducted a first-of-a-kind research combining solar technology with ground source heat pump systems developing a solar-ground source heat pump (SGHP) incorporating a vertical double-spiral coil ground heat exchanger (GHX). The new GHX showed 18 times more heat absorption rate per unit of ground surface area than a conventional single-pipe vertical heat exchanger. Also, COP improvements of up to $21 \%$ was recorded reaching peak COP values of 3.5. The study compared analytical model results to experiments and provided a design guidance for the design of integrated solar-ground source heat pumps and GHXs. In another study, Huang and Lee [26] studied the long term performance of a SAHP water heater developed earlier by the authors [23] through a prototype system working continuously for more than 13000 hours. This study mainly focused on reliable and effective operation of the developed system and recorded no system failure during the 5 years operation of the SAHP water heater.

Huang et al. [24] also developed a heat-pipe enhanced SAHP water heater in 2005 which was a modification of their earlier water heater system [23] employing solar heat-pipe collectors instead of conventional solar collectors. The system was capable of operating in heat-pipe mode when there was sufficient solar energy to provided water heating requirements and hence the heat pump was taken out of the operation to reduce electricity consumption. In high demand periods, the heat pump was added to the cycle creating a DXSAHP system and increase system output. The COP heat-pipe operation mode (3.3) was $28.7 \%$ more than the heat pump operation mode (2.6), and the heat-pipe addition to the original design using conventional solar collectors showed to improve performance considerably. The last study to be reflected in this section is a numerical and dynamic 
thermal simulation work carried out by Argiriou et al. [33] on a solar-assisted single stage Li$\mathrm{Br}$ absorption heat pump for residential applications. The simulations were run for three climates in Greece, France, and Germany on a low and a high mass building blocks investigating the performance of system with three solar collector types. Without providing any evidence on impact of such assumption on model predictions, and with no model validation, the study found that the investigated system was capable of achieving $20-27 \%$ energy savings.

A look at the studies carried out in the first five years of $21^{\text {st }}$ century, as summarised in Error! Reference source not found., reveals that majority of the works on SAHP systems have taken place in East Asian countries. The reasons for such trend are more severe climates, more population intensity and scarcity of fossil fuel resources, all demanding more efficient and reliable heating and cooling systems with capacity to reduce electricity consumption and consequently carbon emissions. There was a wide range of COP values recorded by different studies during this period, ranging from 1.5 to 9 under various climate conditions, refrigerant choice and system characteristics suggesting that the technology was at its early years of design and test with an overview of being implemented in future. As for the investigation methods, the key approaches were experiments and analytical modelling incorporating basics of heat transfer and thermodynamics.

\subsection{Key limitations of the SAHP technologies in the first quarter}

Following the review of research carried out in the first quarter of the century, the key technological and methodological limitations were identified as:

- Lack of alternatives for the banned refrigerants and very limited evidence of studies investigating suitable refrigerant for DX-SAHPs,

- Lack of robust and reliable numerical simulation methods,

- Lack of standardised methodology or guidelines for effective design and implementation of DX-SAHPS,

- Limited application of efficient and effective heat and mass storages (i.e. corrugated),

- Low efficiencies associated with flat plate collectors and lack of investigation for more efficient collectors. 
Table 2 Summary of all the studies investigated in the first quarter (2000-2005) with particular attention to location of study, type of investigated SAHP system, analysis method, and system performance (COP)

\begin{tabular}{|c|c|c|c|c|c|c|}
\hline Year & Source & Location & System type & Analysis method & COP values & Study's focus \\
\hline 2001 & Hawlader et al. [22] & Singapore & DX-SAHP with R-134A & $\begin{array}{l}\text { Experiment + Analytical } \\
\text { model + Economic analysis }\end{array}$ & $4-9$ & $\begin{array}{l}\text { Impact of collector area, speed of the compressor, } \\
\text { and solar irradiation on COP }\end{array}$ \\
\hline 2001 & Huang \& Chyng [25] & Taiwan & DX-SAHP with R-134A & $\begin{array}{l}\text { Experiment }+ \text { Analytical } \\
\text { model }\end{array}$ & $2.5-3.7$ & $\begin{array}{l}\text { Adjustment of expansion valve opening for } \\
\text { performance improvement }\end{array}$ \\
\hline 2002 & Badescu [28], [29] & Romania & DX-SAHP with R-114 & Analytical model & $1.5-5.3$ & First and second law analysis \\
\hline 2003 & Hawlader et al. [30] & Singapore & $\begin{array}{l}\text { SAHP with unidentified } \\
\text { refrigerant }\end{array}$ & $\begin{array}{l}\text { Experiment + Analytical } \\
\text { model }\end{array}$ & $5-7$ & $\begin{array}{l}\text { Conventional SAHP with two loops: air and } \\
\text { refrigerant, for drying and water heating }\end{array}$ \\
\hline 2003 & Kuang et al. [31] & China & $\begin{array}{l}\text { DX-SAHP with water as } \\
\text { refrigerant }\end{array}$ & Experiment & $2.2-2.6$ & $\begin{array}{l}\text { A water source heat pump and water-based solar } \\
\text { collector loop combination }\end{array}$ \\
\hline 2003 & Chyng et al. [23] & Taiwan & DX-SAHP with R-134A & $\begin{array}{l}\text { Experiment }+ \text { Analytical } \\
\text { model }\end{array}$ & $1.7-2.5$ & $\begin{array}{l}\text { A DX-SAHP water heater with modelling assumption } \\
\text { of quasi-steady process for all components }\end{array}$ \\
\hline 2004 & Bi et al. [32] & China & $\begin{array}{l}\text { SGHP-GHX with water } \\
\text { as refrigerant }\end{array}$ & $\begin{array}{l}\text { Experiment }+ \text { Analytical } \\
\text { model }\end{array}$ & $2.5-3.5$ & $\begin{array}{l}\text { A SGHP with double-coil GHX capable of switching } \\
\text { between a solar and ground source heat pump }\end{array}$ \\
\hline 2004 & Huang \& Lee [26] & Taiwan & DX-SAHP with R-134A & Experiment & N/A & $\begin{array}{l}\text { A DX-SAHP water heater operated and investigated } \\
\text { continuously for } 13000 \text { hours }\end{array}$ \\
\hline 2005 & Huang et al. [24] & Taiwan & $\begin{array}{l}\text { Heat-pipe enhanced } \\
\text { DX-SAHP with R-134A }\end{array}$ & Experiment & $2.6-3.3$ & $\begin{array}{l}\text { A Heat-pipe enhanced DX-SAHP with R-134A with } \\
\text { improved performance compared to its predecessor } \\
\text { using conventional solar collectors }\end{array}$ \\
\hline 2005 & Argiriou et al. [33] & Greece & $\begin{array}{l}\text { Solar assisted } \mathrm{Li}-\mathrm{Br} \\
\text { absorption heat pump }\end{array}$ & $\begin{array}{l}\text { Numerical/dynamic } \\
\text { thermal model }\end{array}$ & $1.6-2.8$ & $\begin{array}{l}\text { Simulation work on a solar assisted absorption heat } \\
\text { pump suitable for residential buildings }\end{array}$ \\
\hline
\end{tabular}




\section{Second quarter: 2006 to 2010}

\subsection{Increasing interest in Solar-assisted Ground-source Heat Pumps (SGHP)}

The second investigation period coincides with appearance of more research from wider range of countries revealing the increasing interest in SAHP systems across the world. Compared to previous period, more research was carried out on Solar-assisted Groundsource Heat Pumps (SGHP) mainly focusing on the performance improvements through experiments and modelling works [34]-[40]. The first two SGHP research in this period was carried out in Turkey where Hepbasli [34] performed an energy-exergy analysis of a GSHP system with a GHX for domestic use in south of Turkey. The study recorded low COP values of 0.2-0.25. Ozgener and Hepbasli [35] later improved their design and examined the SGHP system for heating greenhouses. The improved design was capable of reaching peak COP values of 3.1. Ozgener [39] also integrated a wind turbine unit into the existing SGHP system and investigated its performance for agricultural purposes, achieving COP values of 2-2.8 through experiments and modelling work. Other studies in China also investigated performance of various SGHP systems with a wide range of design parameters, operating conditions and heat exchanger configurations [36]-[38], [40].

Han et al. [36] for the first time used numerical modelling, as opposed to analytical models used previously, to investigate a SGHP system incorporating a latent heat storage unit for severely cold areas of China. The latent heat storage unit was designed in the form of Utube ground exchanger which was connected to a storage tank with encapsulated Phase Change Materials (PCM). While no uncertainty analysis was performed to analyse the impact of assumptions on model predictions, and without an empirical validation of the model, the COP of the SGHP was found to be 3.3-6 in heating season; and the authors highlighted the positive contribution of the latent heat storage unit to achieved high COP values [36]. Wang et al. [40] later performed an experimental investigation of the same SGHP system, in a detached house in suburbs of Harbin province of China, and found the COP values to be in the range 4.3-6.6 which greatly overlapped with the numerical model's predictions. 
Wang and Qi [37], and Wang et al. [38] performed an extensive analysis of a SGHP unit with an underground storage unit to provide domestic space heating and cooling in Tianjin province of China. The numerical modelling work was carried out in TRNSYS software package and model was validated empirically using the experimental results. The only mentioned assumption made in the modelling work was that the water tank is assumed to be fully mixed and temperature distribution to be homogenous [37], [38]. The COP values achieved from validated numerical model under various operating conditions were in the range 3.8-5.3.

\subsection{Numerical simulation of performance, and first appearance of $A I$}

The increasing interest in employing numerical modelling and the great flexibility offered by advanced computational software and hardware developments can be identified as another key milestone in SAHP research. More studies started using the numerical models which are capable of taking into account the transient behaviours of the system offering closer predictions to experimental results and higher accuracy in predicting real-life performance of SAHP systems. The first appearance of Artificial Intelligence (AI) applications in SAHP research was also observed in the second quarter of $21^{\text {st }}$ century. Mohanraj et al. [41] for the first time used Artificial Neural Networks (ANN), as the most popular deep learning technique, to predict the performance of a DX-SAHP in Calicut city, India. Although the first Al application in SAHP research appeared in 2009, the ANN technique was previously used for various engineering purposes, from investigating performance of a vapour compression liquid chiller [42], [43] to investigating performance of air and ground source heat pumps, and various energy systems for a wide range of applications [44]-[48]. The ANN is described and fully investigated for various applications elsewhere [49]-[52].

The work by Mohanraj et al. [41] used various performance parameters like heating capacity, compressor discharge temperature, electricity consumption of the system, and COP of the system as the training set for the ANN algorithm, and identified the most suitable ANN method for the investigated DX-SAHP. The performance of ANN numerical model was investigated using three criteria: correlation coefficient $\left(R^{2}\right)$, root mean square error (RMS) and coefficient of variance (COV), and the study found ANN algorithm using Lavenberg-Marguardt [53] method with 10 hidden layer (Error! Reference source not 
found.) was capable of achieving the maximum $R^{2}(0.999)$, minimum $R M S$ and the lowest COV values [41].

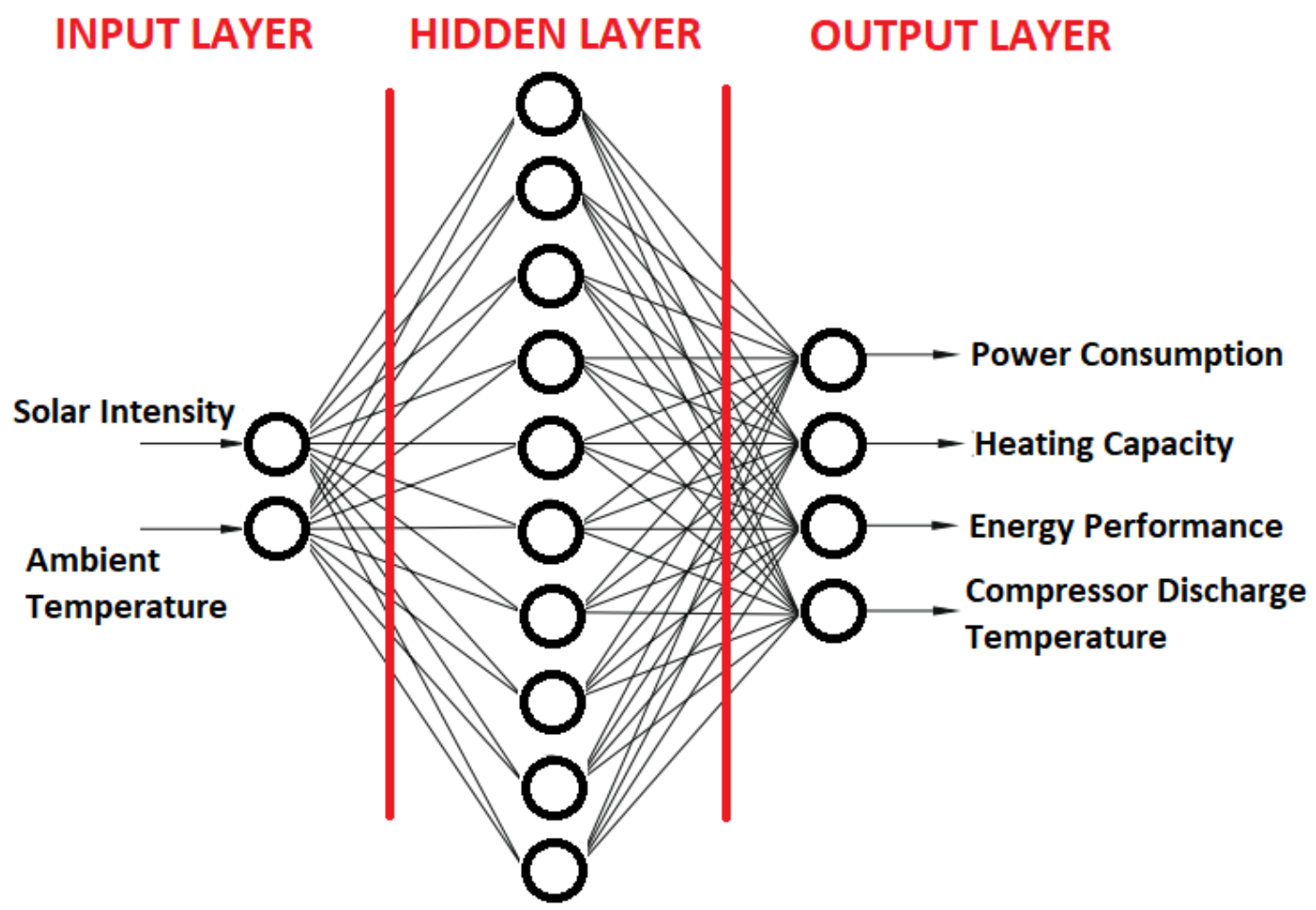

Figure 2 Architecture of the ANN used for DX-SAHP performance prediction (re-created from [41])

\subsection{Other key developments in the second quarter}

Having discussed the latest developments in SGHP systems and numerical model applications in SAHP research, as the key milestones achieved in the second quarter of $21^{\text {st }}$ century, the rest of this section will look into other significate works carried out in this period. Despite the increase in SGHP research in this period compared to the previous period, still the majority of experimental and modelling work was carried out on DX-SAHP with a wide range of operating parameters and design specifications [54]-[64].

Kuang and Wang [54] experimentally investigated the life-time operation of a DX-SAHP which was capable of providing space heating, air conditioning and domestic hot water purposes throughout the year. The system was among the first efforts to utilise the cheaper night-time electricity to run the heat pump and store the energy in a water thermal storage tank for use in daytime. The experimental COP of the system was found to be 2.1-2.7 for the space heating, space cooling and water heating modes of operation. 
Li et al. [55] performed an experimental study of a DX-SAHP with R-22 refrigerant under spring weather conditions of Shanghai, China. The whole system COP ranged between 3.1 and 6.6 to heat up the water in a $150 \mathrm{~L}$ tank from ambient temperature to $50.5^{\circ} \mathrm{C}$. The study found that using an electric expansion valve instead of a conventional thermostatic expansion valve can considerably improve the control accuracy of system and reduce the throttling heat loss, resulting in improve performance of the DX-SAHP system. Huang and Lee [57] performed an experimental and numerical modelling study and derived a simple linear correlation to predict the performance of DX-SAHP systems. The correlation was reached from the energy conservation principle and was verified through long term experimental data for different types of DX-SAHP systems with R-134A refrigerant. Dikici and Akbulut [58] also investigated the performance of a DX-SAHP with R-22 refrigerant through experiments and analytical modelling to provide space heating for domestic use in West of Turkey, and reported an average COP value of 3.1 for the system.

One of the most innovative and highly efficient SAHP systems developed to date was tested by Ji et al. [59], [61] in Hefei, China. The novel DX-SAHP system was enhanced with Photovoltaic and Thermal (PV/T) solar panels which enabled the system to convert solar energy into electricity and heat simultaneously. To achieve this PV cells were bonded onto the evaporator surface with R-22 refrigerant to produce electricity while the solar heat gain was absorbed by the refrigerant tubes behind the PV cells (Figure 3). The system performance was investigated with a numerical and dynamic distributed parameter model with the key assumption of homogenous flow inside the copper refrigerant tube. The model outputs were validated with the experimental results and because of the improved solar absorption of the system and simultaneous power generation, the recorded COP was in calculated as 10.4-16.1, which was the highest value among the SAHP systems [59].

Qi et al. [60] simulated the operation of a DX-SAHP with PCM seasonal storage unit through a simplified mathematical/analytical model. The investigated storage tank was cylindrical one filled with PCM tubes. Since PCM storage units started to gain more attention from the SAHP research, the schematic of a storage tank with inner PCM tubes as depicted by Qi et al. [60] is presented here as a reference point for further analysis of such storage unit (Figure 4). 


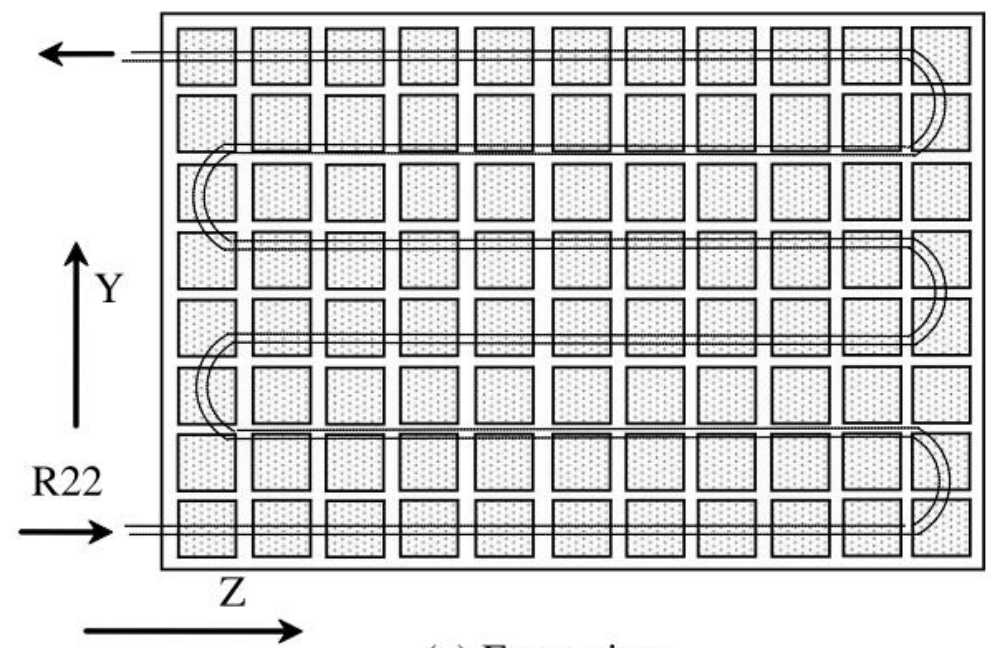

(a) Front view

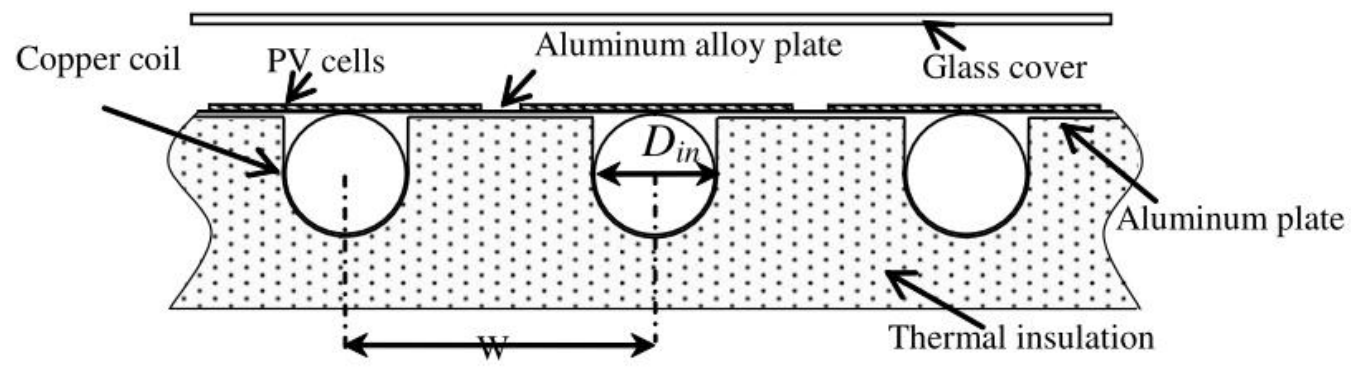

(b) Cross-sectional view (part plan)

Figure 3 Structure of the PV/T panels for simultaneous heat and power generation (permission granted to use the figure from [61])
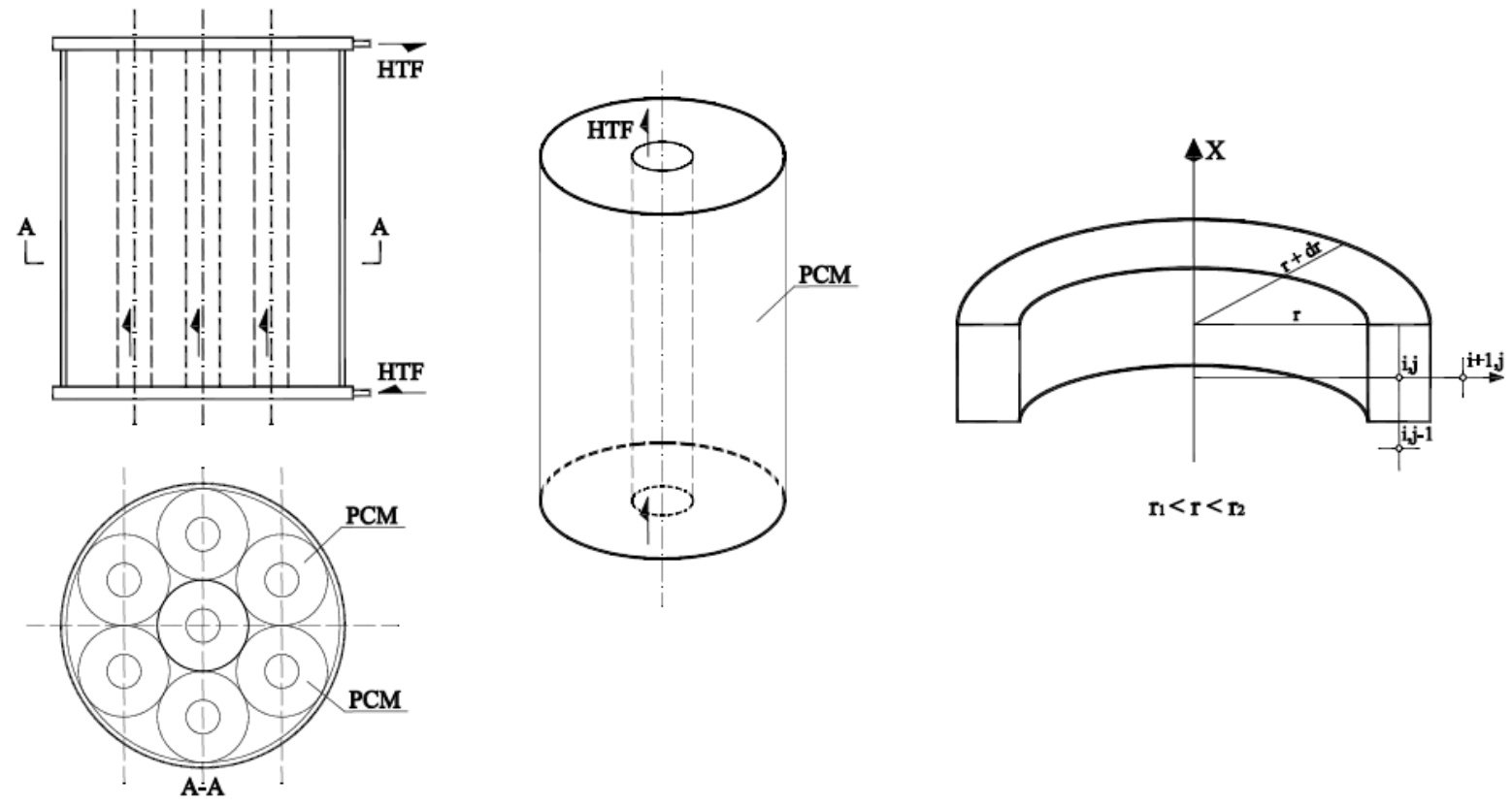

$\mathbf{r}_{1}<$ r $<\mathbf{r}_{2}$

Figure 4 Schematic and configuration of a PCM storage unit with inner PCM tubes (recreated from [60]) 
As seen in Figure 4, the storage unit embedded seven PCM tubes which were made of two concentric cylinders: the inner one for to accommodate refrigerant and the outer one to store Phase Change Material (PCM) which was $\mathrm{CaCl} 2.6 \mathrm{H} 2 \mathrm{O}$ (Calcium Chloride Hexa-Hydrate) in the study by Qi et al. [60]. The developed model focused mainly on the conduction within the PCM neglecting the convection heat transfer and assumed that PCM has a fixed melting point, is homogenous and no degradation happen throughout the operation of system. The simulation results, without any validation and analysis of the impact of each assumption, found a COP value of 4.2 for the whole system operation.

Chaturvedi et al. [62] developed an analytical model to investigate the performance of a two-stage DX-SAHP with R-134A refrigerant for high temperature applications $\left(60-90^{\circ} \mathrm{C}\right)$, and quantified the performance improvements of the system in comparison to a singlestage DX-SAHP. Majority of the DX-SAHP systems investigated so far in this paper focused on low-temperature applications suitable for domestic and some agricultural purposes. The study by Chaturvedi et al. [62] was among the first to modify DX-SAHP systems for high temperature applications required in most industries. Such high temperatures would deteriorate the solar collectors' efficiency and reduce their efficiency considerably. Hence, the authors justified the use of a two-stage design by identifying that the other alternative, using low concentration ratio solar collector which require continuous tracking of the sun, was not cost-effective and wouldn't be interesting to many industries. Although presence of an extra compressor increases the electricity demand of the system, the high temperature output results in high COP values of 2.5-6.

Stojanović and Akander [63] carried out experiments on a DX-SAHP for domestic use in Nordic climates of Sweden. Due to poor insulation levels of the hosting house and extremely low winter-time temperatures, a GHX was used to efficiently and effective store the generated heat for a full-day space heating provision. The recorded Seasonal Performance Factor (SPF) was in the range 2.1-2.9, which authors deemed as successful considering the un-favourable conditions of the hosting house was. Li and Yang [64] developed an analytical model of a SAHP with R-22 refrigerant where the heat pump and solar collectors were operating as two separate units to provide hot water requirements (not a DX-SAHP). In this case, the heat pump was used as an auxiliary unit when the heat from solar collectors were not sufficient for the hot water requirements and the overall COP values of the system were 
in the range 2.7-4.7. Mammoli et al. [56] investigated a solar assisted $\mathrm{Li}-\mathrm{Br}$ absorption heat pump system to provide space cooling. The key idea behind this system was to store the chilled water produced during cheaper off-peak electricity periods and use it for space cooling when required. However, the very low COP values of the system $(0.25-0.4)$ proved the absorption system to be not suitable for low energy and low carbon applications when compared to DX-SAHP units employing air source or ground source heat pumps. Table 3 Summarises all the studies covered in the second quarter of $21^{\text {st }}$ century providing a combination of qualitative and quantitative data on performance and investigation methods of each study.

\subsection{Key limitations of the SAHP technologies in the second quarter}

Following the review of research carried out in the second quarter of the century, the key technological and methodological limitations were identified as:

- Operating temperature limits between the condenser and evaporator temperatures,

- Limited investigation on GHX configuration, efficiencies, and connection to heat pumps,

- Limited application of developed technologies for high temperature applications,

- Lack of investigation on improving life and performance of collectors for high temperature applications,

- Limited evidence of empirical validation of the developed numerical models. 
Table 3 Summary of all the studies investigated in the second quarter (2006-2010) with particular attention to location of study, type of investigated SAHP system, analysis method, and system performance (COP)

\begin{tabular}{|c|c|c|c|c|c|c|}
\hline Year & Source & Location & System type & Analysis method & COP values & Study's focus \\
\hline 2006 & Kuang \& Wang [54] & China & DX-SAHP with R-22 & Experiment & 2.1-2.7 & $\begin{array}{l}\text { A DX-SAHP system for domestic space heating, air } \\
\text { conditioning and hot water provision }\end{array}$ \\
\hline 2007 & Li et al. [55] & China & DX-SAHP with R-22 & Experiment & $3.1-6.6$ & $\begin{array}{l}\text { Experimental and exergy analysis of a DX-SAHP } \\
\text { system to improve components' performance }\end{array}$ \\
\hline 2007 & Hepbasli [34] & Turkey & $\begin{array}{l}\text { SGHP-GHX with water } \\
\text { as refrigerant }\end{array}$ & Analytical model & $0.2-0.25$ & $\begin{array}{l}\text { Energy-exergy analysis of a SGHP system with a GHX } \\
\text { for domestic use }\end{array}$ \\
\hline 2007 & $\begin{array}{l}\text { Ozgener \& Hepbasli } \\
\text { [35] }\end{array}$ & Turkey & $\begin{array}{l}\text { SGHP-GHX with water } \\
\text { as refrigerant }\end{array}$ & $\begin{array}{l}\text { Experiment }+ \text { Analytical } \\
\text { model }\end{array}$ & $2.8-3.1$ & $\begin{array}{l}\text { Experimental analysis and parametric modelling of a } \\
\text { SGHP system with a GHX for heating green houses }\end{array}$ \\
\hline 2007 & Huang \& Lee [57] & Taiwan & DX-SAHP with R-134A & $\begin{array}{l}\text { Experiment }+ \text { Numerical } \\
\text { model }\end{array}$ & $1.9-3.6$ & $\begin{array}{l}\text { Linear correlation for the performance evaluation of } \\
\text { different DX-SAHP systems }\end{array}$ \\
\hline 2008 & Dikici \& Akbulut [58] & Turkey & DX-SAHP with R-22 & $\begin{array}{l}\text { Experiment + Analytical } \\
\text { model }\end{array}$ & 3.1 & $\begin{array}{l}\text { Experimental and energy-exergy analysis of a DX- } \\
\text { SAHP for domestic use in East Turkey }\end{array}$ \\
\hline 2008 & Han et al. [36] & China & $\begin{array}{l}\text { SGHP-GHX with water } \\
\text { as refrigerant }\end{array}$ & Numerical model & $3.3-6$ & $\begin{array}{l}\text { Transient numerical simulation of a SGHP with GHX } \\
\text { and latent heat energy storage in severely cold areas }\end{array}$ \\
\hline 2008 & Wang \& Qi [37] & China & $\begin{array}{l}\text { SGHP-GHX with water } \\
\text { as refrigerant }\end{array}$ & $\begin{array}{l}\text { Experiment }+ \text { Numerical } \\
\text { model }\end{array}$ & $3.8-5.3$ & $\begin{array}{l}\text { Performance analysis of a SGHP with GHX for } \\
\text { domestic heating and air conditioning }\end{array}$ \\
\hline 2008 & Ji et al. [59] & China & $\begin{array}{l}\text { PV enhanced DX-SAHP } \\
\text { with R-22 }\end{array}$ & Experiment & $10.4-16.1$ & $\begin{array}{l}\text { Performance analysis of a PV enhanced DX-SAHP for } \\
\text { space cooling, heating, and hot water provision as } \\
\text { well as electricity generation }\end{array}$ \\
\hline 2008 & Qi, Deng \& Jiang [60] & China & $\begin{array}{l}\text { DX-SAHP with PCM } \\
\text { storage }\end{array}$ & Analytical model & 4.2 & $\begin{array}{l}\text { Numerical simulation of a DX-SAHP with PCM } \\
\text { storage tank as seasonal heat storage medium }\end{array}$ \\
\hline 2009 & $\begin{array}{l}\text { Mohanraj, Jayaraj \& } \\
\text { Muraleedharan [41] }\end{array}$ & India & DX-SAHP with R-22 & $\begin{array}{l}\text { Experiment }+ \text { Numerical } \\
\text { model (Al) }\end{array}$ & N/A & $\begin{array}{l}\text { Suitability of ANN for performance analysis of DX- } \\
\text { SAHP systems supported with experimental analysis }\end{array}$ \\
\hline 2009 & Ji et al. [61] & China & $\begin{array}{l}\text { PV/T enhanced DX- } \\
\text { SAHP }\end{array}$ & $\begin{array}{l}\text { Experiment }+ \text { Numerical } \\
\text { model }\end{array}$ & N/A & $\begin{array}{l}\text { Experimental and dynamic thermal analysis of a PV/T } \\
\text { enhanced DX-SAHP }\end{array}$ \\
\hline
\end{tabular}


2009 Chaturvedi et al.

USA

[62]

2009 Wang et al. [38]

China

2009 Ozgener [39]

Turkey

2010 Wang et al. [40]
Two-stage DX-SAHP with R-134A

SGHP-GHX with water

as refrigerant

Wind turbine

enhanced SGHP

China
Analytical model

Experiment + Analytica

model

Experiment + un-identified model

Experiment
$2.5-6$

3.8-5.3

$2-2.8$

4.3-6.6
Two-stage DX-SAHP systems for high temperature applications in the range of $60-90^{\circ} \mathrm{C}$

Performance of SGHP-GHX system for residential building for a range of operating conditions

Modelling integration of wind turbine to SGHP systems for domestic and agricultural use

Experimental analysis of a SGHP with GHX and latent heat energy storage for domestic use in cold areas 


\section{Third quarter: 2011 to 2015}

\subsection{Age of Photovoltaic/Thermal (PV/T) enhanced heat pumps for simultaneous heat and}

power generation

Upon successful operation and improved performance parameters introduced by PV enhanced SAHP systems in the previous period [59], [61], the third quarter of $21^{\text {st }}$ century saw an overwhelming increase in the number of research from all over the world dedicated to systems with capacity to simultaneously generate heat and power from solar energy. The use of a hybrid PV/T technology is well justified compared to separately installed PV and thermal solar collector units as the PV/T systems can considerably reduce the space requirements and initial installation and operation costs while improving the performance parameters. Despite the first reported work on PV/T collectors dating back to 1955 by Bergene and Martin Lovvik [65], the integration of such collectors with heat pump systems wasn't investigated until early 2000s. The performance of PV/T collectors and the advantages they offer for various applications, however, was investigated extensively [65][74]. In 1955, Bergene and Martin Lovvik [65] developed an analytical model of PV/T collectors and made quantitative predictions of the system performance and proposed possible applications for PV/T collectors. Later in 1981, Raghuraman [67] investigated two different PV/T systems through an experimentally validated analytical model. Sandnes and Perkstad [68] studied the effectiveness of a PV/T unit with single-crystal silicon material through experiments and modelling work. Tripanagnostopoulos et al. [69] run experiments on a PV/T collector under Greece weather conditions to provide hot water and electricity for domestic and non-domestic buildings. Chow [70] and Chow et al. [73] developed a dynamic model of a PV/T unit to perform energy and exergy analysis (supported by experiments) under various operating conditions. Wei et al. [71] investigated application of PV/T collectors with natural circulation of water, and Herrando and Markides [74] investigated the techno-economic considerations of using PV/T collectors for heat and power generation in domestic sector of the UK.

Fu et al. [75] was among the first to present the design and experimental analysis of a PV enhanced SAHP system with R-134A refrigerant. The system configuration was very similar to the previous example of the PV enhanced system [59], [61] and authors denoted the 
refrigerant tubes shown in Error! Reference source not found. as the heat-pipes, thus naming the system a photovoltaic solar-assisted heat-pump/heat-pipe system with PV/T collectors. The experiments were run under weather conditions of Hong Kong, China in November-December 2010 with results showing efficiency of $61-82 \%$ and COP values of 2.5 4.9. Zhang et al. [76] performed a numerical modelling and experimental study with focus on operating principle of PV enhanced SAHP systems in order to achieve higher COP values. The experiment outputs revealed that the electrical, thermal and overall efficiencies were $10 \%, 40 \%$, and $50 \%$, respectively resulting in the overall system COP value of 8.7 . The experimental and modelling results revealed that the low solar radiation rate and ambient temperature of the UK weather, improved the electrical efficiency of system but reduced the thermal efficiency. However, the drop in thermal efficiency was easily compensated by introducing higher number of heat-pipes running in parallel behind the PV cells.

Thygesen and Karlsson [77], [78] performed two numerical modelling studies to investigate performance of three SAHP systems, namely, PV enhanced, solar thermal enhanced, and PV/T enhanced heat pump systems for building integration under Sweden's weather conditions. The authors found that, compared to stand alone heat pump systems, all three SAHP systems offered higher performance values (COP of 3.1) for heat and power provision to Swedish homes. The authors also investigated two different energy storage mediums for the PV enhanced heat pump system: One with $48 \mathrm{kWh}$ batteries to store electricity, and the other with a hot water storage tank where the electricity is stored as heat. The study found that the system with batteries and thermal storage could reach $89 \%$ and $88 \%$ electricity selfconsumption, respectively. Another European study was carried out by Hazi and Hazi [79] where a computer model was introduced to investigate the efficiency and effectiveness of PV/T enhanced DX-SAHP systems for various high-temperature industrial applications under the weather conditions of Bacau, Romania. Similar to the research by Thygesen and Karlsson [77], [78], the numerical model developed by Hazi and Hazi [79] also lacked a robust validation and uncertainty analysis to ensure accuracy of the results.

Gunasekar et al. [80] further established the Al applications in the SAHP research (followed by Mohanraj et al. [41]) and studied the performance of a PV/T enhanced SAHP system with R-134A refrigerant through ANN modelling. The modelling results were supported and validated by experimental analysis of the system under weather conditions of the 
Coimbatore city, India between January and March 2014. The impact of various operating parameters on system performance was investigated and the ambient temperature together with solar intensity were found to have the largest effect on the system COP values which were recorded at the range 2.4-2.6. Xu et al. [81] were among the first to investigate performance of PV/T enhanced SAHP systems with low-concentrating solar panel instead of conventional flat plate collectors with glass cover (Figure 5). As seen in Figure 5, the parabolic concentrator located around the PV cells reflects the sunlight toward the cells increasing the efficiency of solar collector. The important requirement of such collectors is the ability to track the sun in order for the parabolic concentrator to direct the light in correct direction. However, the authors eliminated the solar tracking feature of the collectors to simplify the design and make its implementation to vast majority of buildings easier by reducing initial and operating costs. Despite identifying the impact of not using sun tracking system as a potential reason for reduced performance of the system, authors reported relatively high COP value of 4.8 as result of experiments in Nanjing, China. It was also found that the electricity output of a certain area of PV cells was 1.6 time more in lowconcentrated collectors compared to the flat plate ones.
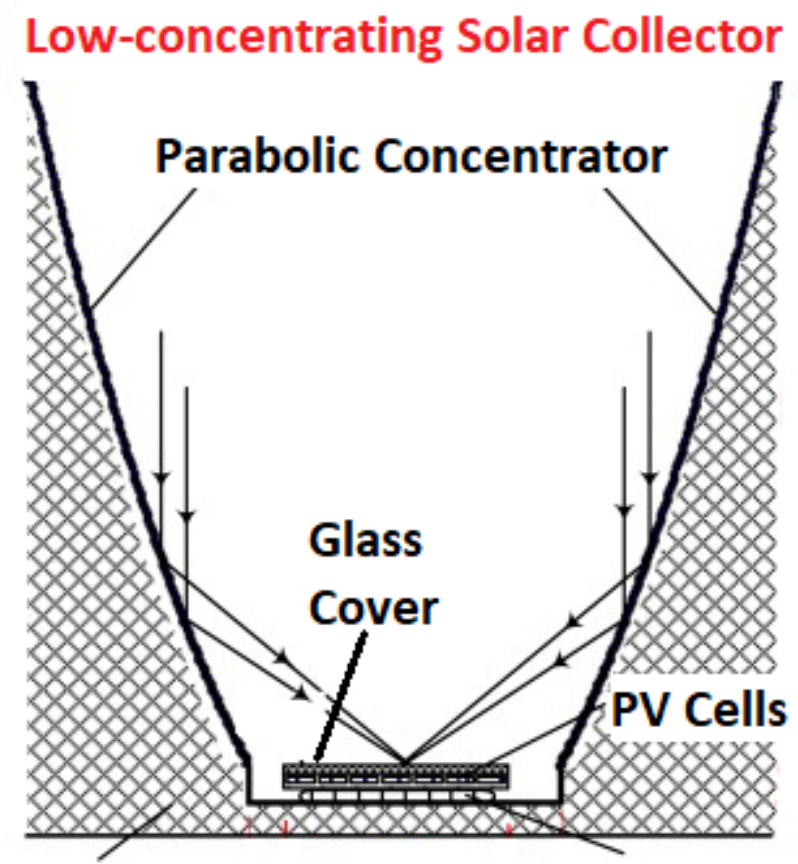

Wooden Base

Refrigerant Tubes

Figure 5 Schematic configuration of low-concentrating solar collectors (re-created from [81]) 


\subsection{Other key development in the third quarter}

A vast majority of research was also carried out on various configuration and potentials of the DX-SAHP and SGHP systems [82]-[90]. The rest of this section will look in to further developments in the DX-SAHP and SGHP systems research, critically analysing the improvement they offer and the applications they can be implemented into. Xi et al. [82] studied the long term performance of a SGHP with underground heat storage unit for hot water and space heating provision. The numerical simulation and optimisation of the investigated system was carried out in TRNSYS software package for 20 years of weather data collected for Bejing, China. System performance was tested under six modes of operations recording COP values of 3.4-4.2, and $26 \%$ performance improvement compared to conventional stand-alone ground source heat pump systems.

Çağlar \& Yamalı [83] performed an experimental and analytical modelling of a DX-SAHP system with an evacuated tubular collector for space heating provision in Turkey. The authors justified the use of evacuated tubular collectors by providing evidence on improved performance of such collectors due to the reduction in heat loss through vacuum technology. The choice of the refrigerant in this study (R-407C) was unconventional when compared to similar studies at the same period, however no justification or impacts of using R-407C refrigerant on system performance weren't provided. Regardless, the study was able to achieve a good agreement between model and experimental results while recording high COP values of 5.6-6.4, which highlighted the potential of evacuated tubular collectors and possibly R-407C refrigerant for offering improved system performance.

Chow et al. [84] run a numerical and economic analysis of a DX-SAHP with R-22 refrigerant to provide water and space heating for an indoor swimming pool under subtropical climates. The transient simulation of the system performance was carried out in TRNSYS software package and overall COP of 4.5 was identified for the system with payback time of less than 5 years. The authors claimed addition savings could be achieved if the system application was extended to space cooling and dehumidification in summer time. Yumurtaş \& Ünsal [85] developed a numerical model of a DX-SAHP system with GHX unit for domestic use. The study investigated connection of discrete energy models for the dwelling, the heat pump, useful solar heat, and the thermal energy storage tank. Without offering a robust 
validation for the developed models, the study recorded high COP values of 4.9-8.9. Wang et al. [86] also carried out a numerical modelling exercise to identify the performance of SGHP system with GHX for space heating and cooling of office buildings. The authors identified the key challenge in design of the SGHP systems with GHX as ground temperature imbalance which was resolved by incorporating Borehole Thermal Energy Storage (BTES) into system design. The study recorded COP values of 4.5-5.2 highlighting the positive contribution of the BTES to improved system performance.

Moreno-Rodriguez et al. [87] performed experimental analysis and analytical modelling of a DX-SAHP with R-134A with a prototype constructed and tested in Spain. The authors carried out a detailed uncertainty analysis including the experimental and simulation errors. The maximum error recorded was $5 \%$ with system COPs of 2.1-2.9. Rad et al. [88] carried out a numerical modelling exercise to identify the applicability of SGHP systems to cold climates of Canada with heating dominated buildings. The study found that employing solar thermal panels as heat storage medium can reduce the length of GHX by $15 \%$ and the system performance was found to be the highest in Vancouver which had the mildest climate.

Dai et al. [89] studied the performance of a SGHP with GHX and R-22 refrigerant under different operating conditions during the coldest month (January) of Dalian, China. System performance was investigated under six different operation modes yielding COP values of 2.7-4.1. The study found that the solar thermal storage accelerates the soil heat recovery when the heat pump is not operational with optimised design of heat storage tank with regards to water temperature. Emmi et al. [90] also investigate the performance of a SGHP system in cold climates through a numerical modelling work carried out in TRNSYS software package. The six locations to investigate performance of the system was chosen based on the classifications identified by Köppen [91], Geiger [92], and ASHRAE [93] which are the common sources of the climate weather data for various energy analysis studies. Similar to the study by Wang et al. [86], the authors found that linking solar panels with ground source heat pump help to eliminate ground temperature imbalance problems resulting in better performance of SGHP systems (COP of 3-4.5) in colder climates when compared to conventional ground source heat pumps. Table 4 Summarises all the studies covered in the third quarter of $21^{\text {st }}$ century providing a combination of qualitative and quantitative data on performance and investigation methods of each study. 


\subsection{Key limitations of the SAHP technologies in the third quarter}

Following the review of research carried out in the third quarter of the century, the key technological and methodological limitations were identified as:

- Limited cost and environmental investigation of the tri-generation technologies,

- Limited investigation of heat-pipe materials exploring potential improvements,

- Limited investigation of power storage options for PV integrated modules,

- Limited number of long-term experimental investigations identifying reliability of developed technologies. 
Table 4 Summary of all the studies investigated in the third quarter (2011-2015) with particular attention to location of study, type of investigated SAHP system, analysis method, and system performance (COP)

\begin{tabular}{|c|c|c|c|c|c|c|}
\hline Year & Source & Location & System type & Analysis method & COP values & Study's focus \\
\hline 2011 & $\begin{array}{l}\text { Xi, Lin \& Hongxinng } \\
{[82]}\end{array}$ & China & $\begin{array}{l}\text { SGHP with water as } \\
\text { refrigerant }\end{array}$ & $\begin{array}{l}\text { Experiment }+ \text { Numerical } \\
\text { model }\end{array}$ & $3.4-4.2$ & $\begin{array}{l}\text { Long term testing, numerical simulation, and } \\
\text { optimisation of a SGHP for a } 20 \text { years operation }\end{array}$ \\
\hline 2012 & Çağlar \& Yamalı [83] & Turkey & DX-SAHP with R-407C & $\begin{array}{l}\text { Experiment }+ \text { Analytical } \\
\text { model }\end{array}$ & $5.6-6.4$ & $\begin{array}{l}\text { A DX-SAHP with evacuated tubular collector for } \\
\text { domestic space heating }\end{array}$ \\
\hline 2012 & Chow et al. [84] & China & DX-SAHP with R-22 & $\begin{array}{l}\text { Numerical model + } \\
\text { Economic analysis }\end{array}$ & 4.5 & $\begin{array}{l}\text { A DX-SAHP for indoor swimming pool water and } \\
\text { space heating in subtropical weather conditions }\end{array}$ \\
\hline 2012 & Fu et al. [75] & China & $\begin{array}{l}\text { PV/T and heat-pipe } \\
\text { enhanced DX-SAHP } \\
\text { with R-134A }\end{array}$ & $\begin{array}{l}\text { Experiment + Analytical } \\
\text { model }\end{array}$ & $2.5-4.9$ & $\begin{array}{l}\text { Design and performance of a photovoltaic solar- } \\
\text { assisted heat-pump/heat-pipe hybrid system }\end{array}$ \\
\hline 2012 & $\begin{array}{l}\text { Yumurtaş \& Ünsal } \\
\text { [85] }\end{array}$ & Turkey & DX-SAHP with GHX & Numerical model & 4.9-8.9 & $\begin{array}{l}\text { Energy analysis of DX-SAHP with GHX for domestic } \\
\text { space heating and hot water provision }\end{array}$ \\
\hline 2012 & Wang et al. [86] & $\begin{array}{l}\text { China / } \\
\text { Canada }\end{array}$ & $\begin{array}{l}\text { SGHP-GHX with water } \\
\text { as refrigerant }\end{array}$ & Numerical model & $4.5-5.2$ & $\begin{array}{l}\text { Performance of hybrid SGHP for space heating and } \\
\text { cooling of office buildings }\end{array}$ \\
\hline 2013 & $\begin{array}{l}\text { Moreno-Rodriguez } \\
\text { et al. [87] }\end{array}$ & Spain & DX-SAHP with R-134A & $\begin{array}{l}\text { Experiment }+ \text { Analytical } \\
\text { model }\end{array}$ & 1.9-2.7 & $\begin{array}{l}\text { Experimental and analytical model analysis of a } \\
\text { prototype DX-SAHP for fan-coil space hating }\end{array}$ \\
\hline 2013 & Zhang et al. [76] & UK & $\begin{array}{l}\text { PV/T and heat-pipe } \\
\text { enhanced DX-SAHP }\end{array}$ & $\begin{array}{l}\text { Experiment + Numerical } \\
\text { model }\end{array}$ & 8.7 & $\begin{array}{l}\text { A novel solar photovoltaic/loop-heat-pipe (PV/LHP) } \\
\text { heat pump system for hot water generation }\end{array}$ \\
\hline 2013 & Rad et al. [88] & Canada & $\begin{array}{l}\text { SGHP-GHX with water } \\
\text { as refrigerant }\end{array}$ & Numerical model & $2.7-10$ & $\begin{array}{l}\text { Feasibility analysis of SAHP systems for use in cold } \\
\text { climate of Canada }\end{array}$ \\
\hline 2013 & $\begin{array}{l}\text { Thygesen \& Karlsson } \\
\text { [77] }\end{array}$ & Sweden & $\begin{array}{l}\mathrm{PV} \text {, Thermal, and PV/T } \\
\text { enhanced SAHP }\end{array}$ & Numerical model & $0.1-3.1$ & $\begin{array}{l}\text { Economic and energy analysis of three SAHP systems } \\
\text { for use in near-zero energy buildings of Sweden }\end{array}$ \\
\hline 2014 & $\begin{array}{l}\text { Thygesen \& Karlsson } \\
\text { [78] }\end{array}$ & Sweden & $\begin{array}{l}\text { PV enhanced SAHP } \\
\text { with thermal and } \\
\text { electrical storage units }\end{array}$ & Numerical model & $N / A$ & $\begin{array}{l}\text { A PV-SAHP system with two different energy storage } \\
\text { technologies: a } 48 \mathrm{~kW} \text { h of batteries, and a hot water } \\
\text { storage tank to store electricity as heat }\end{array}$ \\
\hline
\end{tabular}


2014 Hazi \& Hazi [79]

Romania

PV/T enhanced DX-

\section{SAHP}

2015 Gunasekaret et al. [80]

2015 Dai et al. [89]

China

PV/T enhanced DX-

SAHP with R-134A

SGHP+GHX with R-22

Experiment + Numerica

model (AI)

2015 Emmi et al. [90]

Italy

SGHP+GHX with water

as refrigerant

Numerical model

PV/T enhanced DX-

SAHP with R-134A
1.5-2.7 Comparative study of two PV/T enhanced DX-SAHP systems for industrial hot water provision

2.4-2.6 Performance analysis of a PV/T enhanced DX-SAHP through ANN for India's climate

2.7-4.1 Experimental analysis of a SGHP system under six different operation modes and conditions

3.4-5 Performance of SGHP for six locations in cold climates using test reference year (TRY) weather data and the most suitable control strategy 


\section{Fourth quarter: 2016 to 2020}

In the final investigation period, a vast majority of the research carried out on SAHP systems employed PV/T enhanced collectors following the successful test and operation of the PV/T enhanced SAHP systems reported in previous two periods (2005-2015). Numerous research investigated the characteristics and performance of PV/T enhanced SAHPs, under a wide range of operating conditions, for various weather conditions and applications [94]-[104]. To achieve additional improvements in the performance and economic benefits of the PV/T enhanced systems, two key technologies were gaining more attention in this period, namely, Micro-channel heat-pipes [94], [102], [105], [106], and PCM storage units [104], [107]-[109]. The rest of this section will first review the PV/T enhanced systems, systems employing micro-channel heat-pipes and PCM storage in a chronological order, and then discuss all other types of SAHP systems investigated in the fourth and last quarter of the $21^{\text {st }}$ century (2015-2020).

\subsection{Dominance of Photovoltaic/Thermal (PV/T) enhanced heat pumps, and appearance} of micro-channel heat-pipes

For the first time in 2016, Zhou et al. [94], [102] run experiments to investigate performance of a PV/micro-channel enhanced DX-SAHP system with R-410A refrigerant. The key and most innovative part of this research was the parallel micro-channel evaporator which had increased vapour flow rate resulting in higher refrigerant evaporation, and consequently higher power and heat generation. The new system was capable of achieving thermal and overall efficiencies of $56.6 \%$ and $69.7 \%$, respectively, and overall COP of 4.7 . As the first effort in micro-channels integration to PV collectors, the schematic of the PV/micro-channel solar panels is presented in Figure 6. 

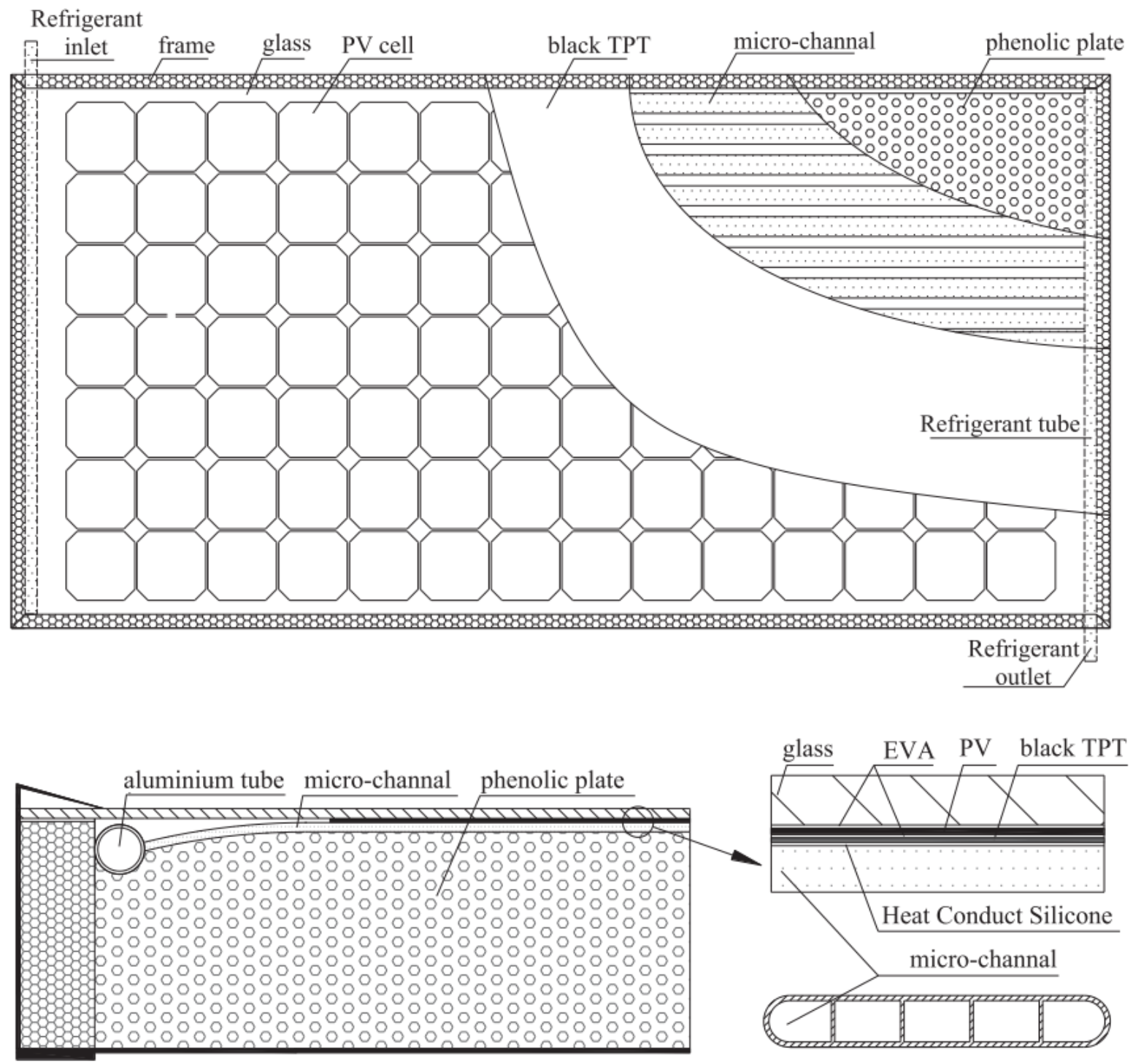

Figure 6 Structure (top) and cross-section view (bottom) of the PV/micro-channelevaporator module (permission granted to use the figure from [94])

The new collectors are made by integrating aluminium micro-channels to the back of conventional PV cells followed by a phenolic plate as insulation. A Black tedlar- polyestertedlar (TPT) is also employed as electrical insulation for the PV cells which enhances the solar irradiation absorption by the PV cells. The liquid refrigerant running inside microchannels absorbs the heat from back of PV cells, vaporises and completes the heat-transfer cycle by running through the compressor. The electricity requirements of the heat pump is partly supplied by the PV cells resulting in near-zero-carbon emissions from the system.

Wang et al. [105] also investigated a PV/T micro-channel enhanced heat pump system through experiments for heat and power generation in a residential building. The system 
was capable of providing heating in winter, cooling in summer, hot water throughout the year and also partially provide domestic electricity demand of the investigated house. The structure of micro-channel heat-pipes used by Wang et al. [105] was very similar to the one presented in Figure 6 with addition of micro-grooves to the micro-channels which increased the heat transfer rate. The flat outer surface of the micro-channels improves the binding of heat-pipes to back of PV cells and reduces the contact thermal resistance. The investigated system recorded COPs of 2.5-3.2 under different modes of operation.

Cai et al. [106] also employed micro-channel enhanced solar collectors to improve the COP of a DX-SAHP system under adverse working settings. The performance of system was analysed through numerical modelling and COP of 2.7 was achieved. The authors found that due to higher heat generation capacity of the SAHP system, the heat pump had a complementary role at most of operating conditions. The majority of heat loss was found to happen in the compressor and condensers of the heat pump system.

\subsection{Increasing interest in PCM storage}

Use of PCMs as heat storage units has been gaining more attention in recent years. Youssef et al. [107] investigated the impact of a PCM based latent heat storage unit when employed in parallel with a DX-SAHP system using R-134A refrigerant for domestic hot water provision. The PCM material used in this study was paraffin with main responsibility of storing excess solar energy in day-time and act as heat source for the heat pump in nighttime operation of the system. The study found that, when compared to systems without PCM storage, the investigated DX-SAHP with PCM storage had 6-14\% higher COP values under different modes of operation. Plytaria et al. [108] also analysed integration of PCM storage to various SAHP and underfloor heating systems. The study carried out an extensive numerical modelling work in TRNSYS software package under winter operating conditions of Athens, Greece, to investigate the performance improvements offered by PCM storage units. The highest performance was recorded for a PV/T enhance SAHP system employing underfloor heating and PCM storage unit with up to $67 \%$ reduction in electricity consumption compared to the systems without PCM storage. Integration of PCM storage to SAHPs also showed a $20 \%$ reduction in variable cost of the system with a payback time of 
18.3 years. The authors also recorded some occupant comfort improvements as result of employing PCM storage in underfloor heating.

Yao et al. [104] studied a PV/T enhanced DX-SAHP with built in PCM storage unit and R-134A refrigerant for high latitude areas of China. The numerical model was developed by integrating three mathematical models of individual system element, namely, PV/T collector and evaporator, PCM heat storage, and compressor. The system showed to be capable of keeping indoor air temperature at $22-31^{\circ} \mathrm{C}$ and reaching COP value of 6.6 which authors claimed is $94 \%$ higher than conventional air conditioning systems. Kutlu et al. [109] also investigated a PV/T enhanced SAHP with PCM storage through numerical simulation and with particular attention to the heat releasing time of the PCM. The modelling work is carried out based on a 24 hour demand profile of typical UK dwelling for space heating and hot water provision under spring and summer weather conditions of the UK. The study found that use of PCM storage helps to tackle the morning peak hot water demand and reduce daily heating energy consumption by up to $13.5 \%$.

In addition to the studies investigating micro-channel heat-pipes and PCM storage units as the emerging technologies of recent years, a vast majority of the research carried out in fourth quarter of the $21^{\text {st }}$ century investigated various configurations of $P V / T$ enhanced SAHP systems [95]-[101], [103], [110]. Calise et al. [95] carried out a numerical simulation and an economic investigation of a PV/T enhanced SAHP system for domestic space heating and cooling, and hot water provision. The study recorded energy efficiency of $49 \%$ and COP values of 2.8-5.8 under various modes of operation and suggested for the system to be profitable a subsidy of $50 \%$ is required. Emmi et al. [97] carried out an experimental and numerical modelling study on a case study PV/T enhanced DX-SAHP system for space heating and hot water provision for single-family dwelling in North East Italy. The study found that PV/T enhanced systems were capable of achieving $16-25 \%$ higher efficiency compared to stand-alone heat pump systems. Li and Sun [98] investigated the operational performance of a PV/Loop-Heat-Pipe enhanced DX-SAHP system through experiments and numerical modelling for hot water provision. The long-term operation of the system was tested through an empirically validated model achieving COP of 3.1. Compared to standalone heat pump systems, a reduction of $30 \%$ was estimated for the total life cycle cost of the system. Bellos and Tzivanidis [101] carried out a multi-objective optimisation of a PV/T 
enhanced DX-SAHP system in winter-time through numerical modelling. Without offering much evidence on model validation the study identified R-32 and R-1234yf as the two most suitable refrigerant for the investigated system with mean energy efficiency of $61 \%$.

Del Amo et al. [100] also investigated a PV/T enhanced DX-SAHP system through and experimentally validated numerical model developed in TRNSYS software package. The authors investigated a wide range of operating parameters and design characteristics of the system to identify the optimum collector and storage size as well as system power requirements. With the optimised system, the study recorded COP values of 3-4.6 with an estimated payback time of six years for the proposed system. Sakellariou et al. [99] performed a modelling exercise to investigate performance of a SGHP system with GHX for domestic space heating and hot water provision to a single-family dwelling in the UK under Birmingham weather conditions. The model was partially validated as an experimentally validated PV/T model was used in conjunction with heat pump, GHX, and building models. Through a detailed sensitivity analysis, storage capacity and heat exchanger effectiveness were found as the two most influential parameters in the performance of investigated system. Shao et al. [103] performed experiments to investigate the performance of PV/T enhanced DX-SAHP system with roof-mounted collectors and R-134A refrigerant. The study recorded COP value of 5.9-8.9, electrical efficiencies of $10.6-11.2 \%$, and thermal and overall efficiencies of 58-56\% in winter. Besagni et al. [110] reported on a field study of a PV/T enhanced DX-SAHP system with R-410A refrigerant as installed in a detached dwelling in Milan, Italy. The study investigated system performance under four different modes of operation and recorded COPs of 2.5-3.8, and PV/T panels were capable of providing $63 \%$ of hot water requirements. Obalanlege et al. [96] carried out a numerical modelling study with quasi-steady state heat transfer and thermodynamic analysis to investigate the effects of various operating parameters on a PV/T enhanced DX-SAHP system with R-407C. The study found peak COP of 4.2 , electrical and thermal efficiencies of $61 \%$ and $64.5 \%$, respectively. The authors claimed that increasing the storage water tank size could lead to efficiency improvements of up to $6.5 \%$.

\subsection{Other key developments in the fourth quarter}


Having discussed the dominant (PV/T enhanced SAHP) and emerging (micro-channels and PCM) technologies in final investigation period of the $21^{\text {st }}$ century, rest of this chapter will look in to all other types of SAHP systems. Shirazi et al. [111] investigated a Solar assisted Li$\mathrm{Br}$ absorption heat pump through numerical modelling under three different control strategies and various auxiliary heater configurations (i.e. series and parallel). The study recorded a low COP value of 0.8 , similar to previous efforts in $\mathrm{Li}-\mathrm{Br}$ absorption heat pumps [33], [56]. Bellos et al [112] were among the first to investigate a SAHP driven by nanofluidbased hybrid PV collectors for space heating and electricity generation. The study found Water/Cu and water/ $/ \mathrm{Al}_{2} \mathrm{O}_{3}$ to be the most efficient nanofluids by employing multi-objective optimisation techniques using energy, exergy and financial criteria. Water/Cu nanofluid was identified as the best heat transfer fluid option achieving $4.8 \%$ higher energy efficiency and $0.7 \%$ higher exergy efficiency compared to pure water. Fraga et al. [113] carried out a numerical sensitivity analysis of a DX-SAHP based on a monitored case study for multifamily buildings in an effort to achieve Seasonal Performance Factor (SPF) of 5. Simulation results were validated with one full year of monitored values achieving a peak SPF value of 4.4. The authors claimed that a SPF of 5 could potentially be achieved, if the building is constructed effectively to have low air leakage, space heating distribution temperature is low, and collector area of at least $0.20 \mathrm{~m}^{2}$ per $\mathrm{m}^{2}$ heated area is provided. Scarpa and Tagliafico [114] carried out an experimental study to investigate exploitation of humid air latent heat by a DX-SAHP. Results showed that the contribution of the condensation is significant $(20 \%-30 \%$ of the total harvested energy) overnight or in cloudy days with very low or no solar irradiation. The study found that the heat due to condensation harvested by the collector is a function of the dew-point temperature only recording COP of 5.8. Razavi et al. [115] presented numerical modelling of performance and dynamic control of a SGHP with GHX for space heating and domestic hot water provision in Zahedan, Iran. The study investigated five operation scenarios through dynamic numerical simulation in TRNSYS software package and proposed a control strategy for each scenario. The best scenario showed to save $9 \%$ energy consumption compared to a representative stand-alone ground source heat pump. The recorded COPs were in the range 3.5-3.8, and similar to previous SGHP research the study found the GHX very effective in increasing evaporator temperature and hence overall COP of the system. 
Weeratunge et al. [116] also proposed a model predictive control strategy for SGHP system with GHX with the main objectives of minimizing operational cost and electricity consumption. The results revealed that the system with GHX reduced the need for expensive peak-time electricity and had $8 \%$ less operating cost in comparison to the system with water storage tank. The study by Fine et al. [117] was another effort to develop a ground thermal response model to analyse its impact of a SGHP system's performance. Mohamed et al. [118] studied a multi-functional DX-SAHP with R-407C refrigerant for space heating in cold climates. The aim of this work was to utilise the waste heat from building and decrease temperature difference between evaporator and condenser. The study recorded COPs of 2.8-3.9 which was claimed to be double the existing DX-SAHP system. Huang et al. [119] also carried out an experimental and numerical modelling study on a DXSAHP system for space heating under frost conditions in China. The study found that with solar irradiance of $100 \mathrm{~W} / \mathrm{m}^{2}$ or with solar irradiance of $0 \mathrm{~W} / \mathrm{m}^{2}$, ambient temperatures of above $-1^{\circ} \mathrm{C}$ and relative humidity of under $70 \%$, no frosts will occur. Finally, a study by Razi and Dincer [124] investigated a solar combined cycle system integrated with a SAHP for providing electrical power, space heating, and cooling, hydrogen, and hot water. This was an important study chosen to conclude this review with, as it investigated the integration of hydrogen into SAHP systems for the first time, establishing a promising trend for the future development of technology. Table 5 Summarises all the studies covered in the fourth and last quarter of $21^{\text {st }}$ century providing a combination of qualitative and quantitative data on performance and investigation methods of each study.

\subsection{Key limitations of the SAHP technologies in the fourth quarter}

Following the review of research carried out in the third quarter of the century, the key technological and methodological limitations were identified as:

- Limited investigation of wind and geothermal sources integration into SAHPs,

- Limited evidence of optimisation studies improving structural design and performance of investigated technologies,

- Limited investigation of micro-channel tubes and possible manufacturing improvement in achieving tubes with finer diameters,

- Limited investigation of suitability of various PCMs for different SAHP configurations. 
Table 5 Summary of all the studies investigated in the fourth quarter (2016-2020) with particular attention to location of study, type of investigated SAHP system, analysis method, and system performance (COP)

\begin{tabular}{|c|c|c|c|c|c|c|}
\hline Year & Source & Location & System type & Analysis method & COP values & Study's focus \\
\hline 2016 & Shirazi et al. [111] & Australia & $\begin{array}{l}\text { Solar assisted } \mathrm{Li}-\mathrm{Br} \\
\text { absorption heat pump }\end{array}$ & Numerical model & 0.8 & $\begin{array}{l}\text { Performance simulation a solar assisted } \mathrm{Li}-\mathrm{Br} \\
\text { absorption chiller under various control strategies } \\
\text { and series/parallel auxiliary heater arrangements }\end{array}$ \\
\hline 2016 & Zhou et al. [94] & UK / China & $\begin{array}{l}\text { PV/Micro-channel } \\
\text { enhanced DX-SAHP } \\
\text { with R-410A }\end{array}$ & Experiment & 4.7 & $\begin{array}{l}\text { Design, construction, and experimental investigation } \\
\text { of a novel PV/Micro-channel-evaporator enhanced } \\
\text { DX-SAHP for use in cold climates }\end{array}$ \\
\hline 2016 & $\begin{array}{l}\text { Scarpa \& Tagliafico } \\
{[114]}\end{array}$ & Italy & DX-SAHP & Experiment & 5.8 & $\begin{array}{l}\text { Experimental exploitation of humid air latent heat } \\
\text { by a DX-SAHP }\end{array}$ \\
\hline 2016 & Calise et al. [95] & Italy & $\begin{array}{l}\text { PV/T enhanced DX- } \\
\text { SAHP }\end{array}$ & Numerical model & $2.8-5.8$ & $\begin{array}{l}\text { Dynamic numerical simulation and thermos- } \\
\text { economic analysis of a novel PV/T enhanced DX- } \\
\text { SAHP for domestic space heating and hot water }\end{array}$ \\
\hline 2017 & Youssef et al. [107] & UK & $\begin{array}{l}\text { DX-SAHP with PCM } \\
\text { storage and R-134A }\end{array}$ & Experiment & $4.2-5$ & $\begin{array}{l}\text { Experimental analysis of the latent heat storage } \\
\text { effects on DX-SAHP for hot water production }\end{array}$ \\
\hline 2017 & Fraga et al. [113] & Switzerland & DX-SAHP & Numerical model & 4.5 & $\begin{array}{l}\text { Numerical sensitivity analysis of a DX-SAHP based on } \\
\text { a monitored case study for multifamily buildings }\end{array}$ \\
\hline 2017 & $\begin{array}{l}\text { Emmi, Zarrella \& De } \\
\text { Carli [97] }\end{array}$ & Italy & $\begin{array}{l}\text { PV/T enhanced DX- } \\
\text { SAHP }\end{array}$ & $\begin{array}{l}\text { Experiment }+ \text { Numerical } \\
\text { model }\end{array}$ & $2.6-4.3$ & $\begin{array}{l}\text { A case study of a multi-source energy system (PV/T } \\
\text { enhanced DX-SAHP) for space heating and hot water }\end{array}$ \\
\hline 2018 & $\begin{array}{l}\text { Razavi, Ahmadi \& } \\
\text { Zahedi [115] }\end{array}$ & Iran & $\mathrm{SGHP}+\mathrm{GHX}$ & Numerical model & $3.5-3.8$ & $\begin{array}{l}\text { Numerical modelling of a SGHP+GHX under five } \\
\text { different operation scenarios and control strategy }\end{array}$ \\
\hline 2018 & $\begin{array}{l}\text { Weeratunge et al. } \\
{[116]}\end{array}$ & Australia & $\mathrm{SGHP}+\mathrm{GHX}$ & Numerical model & 3.8 & Model predictive control for a SGHP+GHX \\
\hline 2018 & Li \& Sun [98] & China & $\begin{array}{l}\text { PV/T enhanced DX- } \\
\text { SAHP }\end{array}$ & $\begin{array}{l}\text { Experiment }+ \text { Numerical } \\
\text { model }\end{array}$ & 3.10 & $\begin{array}{l}\text { Performance analysis of a PV/T enhanced DX-SAHP } \\
\text { for hot water provision in Qinhuangdao City, China }\end{array}$ \\
\hline 2018 & Fine et al. [117] & Canada & $\mathrm{SGHP}+\mathrm{GHX}$ & Numerical model & & $\begin{array}{l}\text { A time-stepping model to analyse ground thermal } \\
\text { response of a SGHP+GHX system }\end{array}$ \\
\hline
\end{tabular}




\begin{tabular}{|c|c|c|c|c|}
\hline 2018 & Wang et al. [105] & China & $\begin{array}{l}\text { PV/ Micro-channel- } \\
\text { enhanced DX-SAHP }\end{array}$ & Experiment \\
\hline 2019 & Bellos et al. [112] & Greece & $\begin{array}{l}\text { PV/T enhanced DX- } \\
\text { SAHP }\end{array}$ & Numerical model \\
\hline 2019 & $\begin{array}{l}\text { Bellos \& Tzivanidis } \\
{[101]}\end{array}$ & Greece & $\begin{array}{l}\text { PV/T enhanced DX- } \\
\text { SAHP with R-32 \& R- } \\
1234 y f\end{array}$ & Numerical model \\
\hline 2019 & $\begin{array}{l}\text { Mohamed et al. } \\
\text { [118] }\end{array}$ & UK & DX-SAHP with R-407C & $\begin{array}{l}\text { Experiment + Numerical } \\
\text { model }\end{array}$ \\
\hline 2019 & Huang et al. [119] & China & DX-SAHP & $\begin{array}{l}\text { Experiment + Numerical } \\
\text { model }\end{array}$ \\
\hline 2019 & Del Amo et al. [100] & Spain & $\begin{array}{l}\text { PV/T enhanced DX- } \\
\text { SAHP }\end{array}$ & $\begin{array}{l}\text { Experiment + Numerical } \\
\text { model }\end{array}$ \\
\hline 2019 & Plytaria et al. [108] & Greece & $\begin{array}{l}\text { DX-SAHP with PCM and } \\
\text { R-134A }\end{array}$ & Numerical model \\
\hline 2019 & Cai et al. [106] & China & $\begin{array}{l}\text { DX-SAHP with finned } \\
\text { tube evaporator }\end{array}$ & Numerical model \\
\hline 2019 & $\begin{array}{l}\text { Sakellariou et al. } \\
\text { [99] }\end{array}$ & UK & $\begin{array}{l}\mathrm{PV} / \mathrm{T} \text { enhanced } \\
\mathrm{SGHP}+\mathrm{GHX}\end{array}$ & Numerical model \\
\hline 2020 & Zhou et al. [102] & UK / China & $\begin{array}{l}\text { PV/ Micro-channel- } \\
\text { enhanced DX-SAHP } \\
\text { with R-22 }\end{array}$ & Experiment \\
\hline 2020 & Yao et al. [104] & China & $\begin{array}{l}\text { PV/T enhanced DX- } \\
\text { SAHP with PCM } \\
\text { storage and R-134A }\end{array}$ & Numerical model \\
\hline 2020 & $\begin{array}{l}\text { Shao, Ma \& Zhang } \\
\text { [103] }\end{array}$ & China & $\begin{array}{l}\text { PV/T enhanced DX- } \\
\text { SAHP with R-134A }\end{array}$ & Experiment \\
\hline 2020 & Besagni et al. [110] & Italy & $\begin{array}{l}\text { PV/T enhanced DX- } \\
\text { SAHP with R-410A }\end{array}$ & Experiment \\
\hline
\end{tabular}

2.5-3.2 Application of a PV/Micro-channel-evaporator enhanced DX-SAHP in residential buildings

N/A DX-SAHP by nanofluid-based hybrid PV collectors for space heating and electricity generation

N/A Design and multi-objective optimisation of a PV/T enhanced DX-SAHP for building applications in winter periods

2.8-3.9 Investigation of a DX-SAHP system performance for space heating and domestic hot water provision

1.6-2.2 Performance analysis of a DX-SAHP system under frost conditions through experiment and modelling

3-4.6 Numerical simulation of PV/T enhanced DX-SAHP system in building with constant thermal demand

5.6-6.4 Investigation of various underfloor DX-SAHP heating systems with and without phase change materials

2.7 Numerical performance analysis of a noel DX-SAHP under different operating conditions

N/A Numerical simulation and sensitivity analysis of a PV/T enhanced SGHP

4.7 Experimental analysis of a PV/Micro-channelevaporator enhanced DX-SAHP for space heating provision in low solar radiation conditions

5.8-6.6 Numerical investigation of a PV/T enhanced DX SAHP with PCM storage for space heat application in high latitude areas

5.9-8.9 Experimental performance analysis of a novel PV/T evaporation roof coupled DX-SAHP system

2.5-3.8 Experimental analysis of a PV/T enhanced DX-SAHP for domestic hot water provision in Milan, Italy 
Performance analysis of a PV/T enhanced DX-SAHP

\section{[96]}

UK

PV/T enhanced DXSAHP with PCM

storage based on quasi-steady state heat transfer and

thermodynamic analysis

3.3-4.6 A numerical analysis of performance improvement of a PV/T enhanced DX-SAHP with PCM storage for UK homes 


\section{Conclusion}

This review investigated all the recent developments and advances in Solar Assisted Heat Pump (SAHP) technologies with particular attention to the type of system, analysis method, performance parameters (COP, SPF, etc), and key focus and findings of each study, as summarised in Tables 2-5. The review of advances in SAHP technologies as presented in this paper only includes the research which was carried out and published in $21^{\text {st }}$ century as older research was found to be of insignificant importance for future developments and advances in the technology. The investigated advances were organised under 4 main time periods (quarters) from 2000 to 2005, 2005 to 2010, 2010 to 2015, and from 2015 to 2020 in order to facilitate chronological review of the related research works. The SAHP systems investigated as part of 72 individual research works, as presented in Tables 2-5, broadly fall within four main categories:

i. Solar Assisted Heat Pumps with conventional compression cycle (SAHP),

ii. Direct Expansion Solar Assisted Heat Pumps (DX-SAHP),

iii. Solar-assisted Ground-source Heat Pumps with Ground Heat Exchanger (SGHP+GHX),

iv. Photovoltaic and Thermal enhanced Solar Assisted Heat Pumps (PV/T enhanced SAHP).

\subsection{Past, current and future trends in advances}

Based on the main focuses of the majority of research carried out in each quarter, the past and current advances recorded so far in the century can be summarised as:

- First quarter (2000-2005): Dominance of R-134A refrigerant and transfer to DX-SAHP,

- Second quarter (2006-2010): Increasing interest in Solar-assisted Ground-source Heat Pumps (SGHP), numerical simulation of performance, and first appearance of $\mathrm{Al}$,

- Third quarter (2011-2015): Photovoltaic/Thermal (PV/T) enhanced heat pumps for simultaneous heat and power generation, and

- Fourth quarter (2016-2020): Dominance of PV/T enhanced heat pumps, appearance of micro-channel heat-pipes and increasing interest in PCM storage.

As for the future trends, it is expected that the current environmentally friendly refrigerants like R-134 continue to be employed by various research and industrial developments. 
However, with fast developing technological advances and more strict rules on ozone depleting substances, it is highly likely that the HFC-based refrigerant be permanently eliminated from the SAHP technologies and be replaced by water-based solutions. In terms of investigation methods, it is expected that the Al applications and various advanced numerical techniques to be accompanied by experimental efforts to expand the technological horizons beyond what has been done so far. The PV/T configurations accompanied by PCM storages are expected to dominate the market with fast developing PCM developments which offer better heat storage and transfer properties. Advances in manufacturing processes would also enable the transfer from micro-channel to Nano-fluid tubes which could further raise the refrigerant flow rate and reduce fluid resistance which will lead to higher performance indicators in SAHP systems.

\subsection{Further research needs}

Following the review presented in this paper, a number of key research needs required for more effective design, investigation, and implementation of various SAHP technologies has been identified:

- Identification of best connection configuration between solar and heat pump loop (i.e. series, parallel, hybrid) based on the solar collectors and heat pump types,

- Identification of best suiting PCM type and volume for different SAHP systems (i.e. DXSAHP, SGHP, PV/T enhanced SAHPs),

- Development of finer micro-channel tubes (Nanotubes) for higher thermal and overall performance of the SAHP systems,

- Optimisation of the existing SAHP configurations to improve performance and reduce heat transfer delays,

- Identification of more environmentally friendly heat transfer media to facilitate elimination of HFC based refrigerants,

- Investigation of the tri- or quadruple- generations system through combining SAHPs with other renewable resources (wind and geothermal),

- Lifecycle and environmental investigation of various SAHP technologies.

\section{Acknowledgments}


The authors would like to acknowledge their appreciation for the financial support received from the project: 'A low carbon heating system for existing public buildings employing a highly innovative multiple-throughout-flowing micro-channel solar-panel-array and a novel mixed indoor/outdoor air source heat pump' funded by the UK BEIS Low Carbon Heating Technology Innovation Fund (LCHTIF1010). Authors confirm that permission is attained for all copyrighted graphics, images, tables and/or figures. 


\section{References}

[1] IEA, "World Energy Outlook," 2019. [Online]. Available: https://www.iea.org/weo2019/. [Accessed: 02-Dec-2019].

[2] L. Perez-Lombard, J. Ortiz, and C. Pout, "A review on buildings energy consumption information '," Energy Build., vol. 40, pp. 394-398, 2008.

[3] A. Badiei, D. Allinson, and K. J. Lomas, "Energy \& Buildings Automated dynamic thermal simulation of houses and housing stocks using readily available re duce $d$ data," Energy Build., vol. 203, 2019.

[4] K. J. Chua, S. K. Chou, W. M. Yang, and J. Yan, "Achieving better energy-efficient air conditioning - A review of technologies and strategies," Appl. Energy, vol. 104, pp. 87-104, 2013.

[5] M. I. Isaac and D. P. Van Vuuren, "Modeling global residential sector energy demand for heating and air conditioning in the context of climate change," vol. 37, pp. 507521, 2009.

[6] M. Scott and Y. Huang, "Annex A: Technical note: methods for estimating energy consumption in buildings in effects of climate change on energy production and use in the United States. A Report by the U.S. climate change science program and the subcommittee on global change resea," Washington (DC), 2007.

[7] Y. Huang, "The impact of climate change on the energy use of the U.S. residential and commercial building sectors," Lawrence Berkeley National Laboratory, Berkeley (CA), 2006.

[8] T. Frank, "Climate change impacts on building heating and cooling energy demand in Switzerland," vol. 37, pp. 1175-1185, 2005.

[9] X. Wang, D. Chen, and Z. Ren, "Assessment of climate change impact on residential building heating and cooling energy requirement in Australia," Build. Environ., vol. 45, no. 7, pp. 1663-1682, 2010.

[10] H. J. Laue, "Heat pumps," in Group VIII advanced materials and technologies, LandoltBörnstein, Ed. Berlin: Heidelberg: Springer, 2006, pp. 26-605. 
[11] R. Daghigh, M. H. Ruslan, M. Y. Sulaiman, and K. Sopian, "Review of solar assisted heat pump drying systems for agricultural and marine products," Renew. Sustain. Energy Rev., vol. 14, no. 9, pp. 2564-2579, 2010.

[12] US-DOS, "Montreal Protocol on Substances that Deplete the Ozone Layer," US Department of State. Office of Environment Quality and Transboundary Issues, 1987. [Online]. Available: https://www.state.gov/key-topics-office-of-environmentalquality-and-transboundary-issues/the-montreal-protocol-on-substances-thatdeplete-the-ozone-layer/. [Accessed: 21-Jan-2020].

[13] UNFCCC, "Kyoto Protocol Reference Manual," United Nations Framework Convention on Climate Change, 2008. [Online]. Available: https://unfccc.int/kyoto_protocol. [Accessed: 21-Jan-2020].

[14] UNFCCC, "Paris Agreement," United Nations Framework Convention on Climate Change, 2015. [Online]. Available: https://unfccc.int/files/essential_background/convention/application/pdf/english_pa ris_agreement.pdf. [Accessed: 21-Jan-2020].

[15] R. Pool, "The Elusive Replacements for CFCs," 1989. [Online]. Available: http://www.ciesin.org/docs/011-490/011-490.html. [Accessed: 21-Jan-2020].

[16] S. K. Chaturvedi and M. Abazeri, "Transient simulation of a capacity-modulated, direct-expansion, solar-assisted heat pump," Sol. Energy, vol. 39, no. 5, pp. 421-428, 1987.

[17] S. K. Chaturvedi, D. T. Chen, and A. Kheireddine, "THERMAL PERFORMANCE OF A VARIABLE CAPACITY DIRECT EXPANSION SOLAR-ASSISTED HEAT PUMP," vol. 39, no. 3, pp. 181-191, 1998.

[18] K. Matsuki, Y. Shinobu, and M. Yoshikawa, "A prototype direct-expansion solar heat pump system," ASHRAE Trans., vol. 93, no. 615, 1987.

[19] K. Matsuki, Y. Shinobu, and M. Yoshikawa, "The performance of the solar heat pump system," J Japan Soc Energy Res, vol. 10, no. 72, 1987.

[20] S. Ito, Y. Naokatsu, and H. Takahashi, "Solar assisted heat pump system," Trans Jpn 
Soc Mech Engrs, vol. 54, no. 1503, 1988.

[21] F. B. G. Chata, S. K. Chaturvedi, and A. Almogbel, "Analysis of a direct expansion solar assisted heat pump using different refrigerants," Energy Convers. Manag., vol. 46, no. 15-16, pp. 2614-2624, 2005.

[22] M. N. A. Hawlader, S. K. Chou, and M. Z. Ullah, "The performance of a solar assisted heat pump water heating system," Appl. Therm. Eng., vol. 21, no. 10, pp. 1049-1065, 2001.

[23] J. P. Chyng, C. P. Lee, and B. J. Huang, "Performance analysis of a solar-assisted heat pump water heater," Sol. Energy, vol. 74, no. 1, pp. 33-44, 2003.

[24] B. J. Huang, J. P. Lee, and J. P. Chyng, "Heat-pipe enhanced solar-assisted heat pump water heater," Sol. Energy, vol. 78, no. 3, pp. 375-381, 2005.

[25] B. J. Huang and J. P. Chyng, "Performance characteristics of integral type solarassisted heat pump," Sol. Energy, vol. 71, no. 6, pp. 403-414, 2001.

[26] B. J. Huang and C. P. Lee, "Long-term performance of solar-assisted heat pump water heater," Renew. Energy, vol. 29, no. 4, pp. 633-639, 2004.

[27] J. G. Cervantes and E. Torres-Reyes, "Experiments on a solar-assisted heat pump and an exergy analysis of the system," Appl. Therm. Eng., vol. 22, no. 12, pp. 1289-1297, 2002.

[28] V. Badescu, "Model of a solar-assisted heat-pump system for space heating integrating a thermal energy storage unit," Energy Build., vol. 34, no. 7, pp. 715-726, 2002.

[29] V. Badescu, "First and second law analysis of a solar assisted heat pump based heating system," Energy Convers. Manag., vol. 43, no. 18, pp. 2539-2552, 2002.

[30] M. N. A. Hawlader, S. K. Chou, K. A. Jahangeer, S. M. A. Rahman, and K. W. Eugene Lau, "Solar-assisted heat-pump dryer and water heater," Appl. Energy, vol. 74, no. 12, pp. 185-193, 2003.

[31] Y. H. Kuang, R. Z. Wang, and L. Q. Yu, "Experimental study on solar assisted heat pump system for heat supply," Energy Convers. Manag., vol. 44, no. 7, pp. 1089- 
1098, 2003.

[32] Y. Bi, T. Guo, L. Zhang, and L. Chen, "Solar and ground source heat-pump system," Appl. Energy, vol. 78, no. 2, pp. 231-245, 2004.

[33] A. A. Argiriou, C. A. Balaras, S. Kontoyiannidis, and E. Michel, "Numerical simulation and performance assessment of a low capacity solar assisted absorption heat pump coupled with a sub-floor system," Sol. Energy, vol. 79, no. 3, pp. 290-301, 2005.

[34] A. Hepbasli, "Exergetic modeling and assessment of solar assisted domestic hot water tank integrated ground-source heat pump systems for residences," Energy Build., vol. 39, no. 12, pp. 1211-1217, 2007.

[35] O. Ozgener and A. Hepbasli, "A parametrical study on the energetic and exergetic assessment of a solar-assisted vertical ground-source heat pump system used for heating a greenhouse," Build. Environ., vol. 42, no. 1, pp. 11-24, 2007.

[36] Z. Han, M. Zheng, F. Kong, F. Wang, Z. Li, and T. Bai, "Numerical simulation of solar assisted ground-source heat pump heating system with latent heat energy storage in severely cold area," Appl. Therm. Eng., vol. 28, no. 11-12, pp. 1427-1436, 2008.

[37] H. Wang and C. Qi, "Performance study of underground thermal storage in a solarground coupled heat pump system for residential buildings," Energy Build., vol. 40, no. 7, pp. 1278-1286, 2008.

[38] H. Wang, C. Qi, E. Wang, and J. Zhao, "A case study of underground thermal storage in a solar-ground coupled heat pump system for residential buildings," Renew. Energy, vol. 34, no. 1, pp. 307-314, 2009.

[39] O. Ozgener, "Use of solar assisted geothermal heat pump and small wind turbine systems for heating agricultural and residential buildings," Energy, vol. 35, no. 1, pp. 262-268, 2009.

[40] X. Wang, M. Zheng, W. Zhang, S. Zhang, and T. Yang, "Experimental study of a solarassisted ground-coupled heat pump system with solar seasonal thermal storage in severe cold areas," Energy Build., vol. 42, no. 11, pp. 2104-2110, 2010.

[41] M. Mohanraj, S. Jayaraj, and C. Muraleedharan, "Performance prediction of a direct 
expansion solar assisted heat pump using artificial neural networks," Appl. Energy, vol. 86, no. 9, pp. 1442-1449, 2009.

[42] H. Bechtler, M. W. Browne, P. K. Bansal, and V. Kecman, "New approach to dynamic modelling of vapour-compression liquid chillers : $\operatorname{arti}^{\circledR}$ cial neural networks," vol. 21 , pp. 941-953, 2001.

[43] D. J. Swider, M. W. Browne, P. K. Bansal, and V. Kecman, "Modelling of vapourcompression liquid chillers with neural networks," vol. 21, pp. 311-329, 2001.

[44] E. Arcaklio, A. Eris, and R. Yilmaz, "Artificial neural network analysis of heat pumps using refrigerant mixtures," vol. 45, pp. 1917-1929, 2004.

[45] A. Badiei, YG. Akhlaghi, X. Zhao, J. Li, F. Yi, Z. Wang, "Can whole building energy models outperform numerical models, when forecasting performance of indirect evaporative cooling systems?," Energy Convers Manage, vol. 213, p. 112886, 2020. 10.1016/j.enconman.2020.112886

[46] YG. Akhlaghi, A. Badiei, X. Zhao, K. Aslansefat, X. Xiao, S. Shittu, X. Ma, "A constraint multi-objective evolutionary optimization of a state-of-the-art dew point cooler using digital twins," Energy Convers Manage, 211, p. 112772, 2020. 10.1016/j.enconman.2020.112772

[47] S. A. Kalogirou, "Applications of $\operatorname{arti}^{\circledR}{ }^{\circledR}$ cial neural-networks for energy systems," vol. 67, pp. 17-35, 2000.

[48] M. Kuan, Ye. Shakir, M. Mohanraj, Ye. Belyayev, S.Jayaraj, A. Kaltayev, "Numerical simulation of a heat pump assisted solar dryer for continental climates," Renewable ENergy, vol. 143, pp. 214-225, 2019.

[49] S. Lek and Y. S. Park, "Artificial Neural Networks," in Encyclopedia of Ecology, Elsevier B.V., 2008, pp. 237-245.

[50] Y. S. Park and S. Lek, "Artificial Neural Networks: Multilayer Perceptron for Ecological Modeling," in Developments in Environmental Modelling, Elsevier B.V., 2016, pp. 123140.

[51] J. A. Carta, "Wind Power Integration," in Comprehensive Renewable Energy, Elsevier 
B.V., 2012, pp. 569-622.

[52] S. Mishra and A. Datta-Gupta, "Data-Driven Modeling," in Applied Statistical Modeling and Data Analytics, Elsevier B.V., 2018, pp. 195-224.

[53] H. P. Gavin, "The Levenberg-Marquardt algorithm for nonlinear least squares curvefitting problems," Department of Civil and Environmental Engineering, Duke University, 2019. [Online]. Available: http://people.duke.edu/ hpgavin/ce281/Im.pdf. [Accessed: 29-Jan-2020].

[54] Y. H. Kuang and R. Z. Wang, "Performance of a multi-functional direct-expansion solar assisted heat pump system," Sol. Energy, vol. 80, no. 7, pp. 795-803, 2006.

[55] Y. W. Li, R. Z. Wang, J. Y. Wu, and Y. X. Xu, "Experimental performance analysis on a direct-expansion solar-assisted heat pump water heater," Appl. Therm. Eng., vol. 27, no. $17-18$, pp. 2858-2868, 2007.

[56] A. Mammoli, P. Vorobieff, H. Barsun, R. Burnett, and D. Fisher, "Energetic, economic and environmental performance of a solar-thermal- assisted HVAC system," Energy Build., vol. 42, no. 9, pp. 1524-1535, 2010.

[57] B. J. Huang and C. P. Lee, "Performance evaluation method of solar-assisted heat pump water heater," Appl. Therm. Eng., vol. 27, no. 2-3, pp. 568-575, 2007.

[58] A. Dikici and A. Akbulut, "Performance characteristics and energy-exergy analysis of solar-assisted heat pump system," Build. Environ., vol. 43, no. 11, pp. 1961-1972, 2008.

[59] J. Ji et al., "Experimental study of photovoltaic solar assisted heat pump system," Sol. Energy, vol. 82, no. 1, pp. 43-52, 2008.

[60] Q. Qi, S. Deng, and Y. Jiang, "A simulation study on a solar heat pump heating system with seasonal latent heat storage," Sol. Energy, vol. 82, no. 8, pp. 669-675, 2008.

[61] J. Ji, H. He, T. Chow, G. Pei, W. He, and K. Liu, "Distributed dynamic modeling and experimental study of PV evaporator in a PV/T solar-assisted heat pump," Int. J. Heat Mass Transf., vol. 52, no. 5-6, pp. 1365-1373, 2009.

[62] S. K. Chaturvedi, T. M. Abdel-Salam, S. S. Sreedharan, and F. B. Gorozabel, "Two-stage 
direct expansion solar-assisted heat pump for high temperature applications," Appl. Therm. Eng., vol. 29, no. 10, pp. 2093-2099, 2009.

[63] B. Stojanović and J. Akander, "Build-up and long-term performance test of a full-scale solar-assisted heat pump system for residential heating in Nordic climatic conditions," Appl. Therm. Eng., vol. 30, no. 2-3, pp. 188-195, 2010.

[64] H. Li and H. Yang, "Study on performance of solar assisted air source heat pump systems for hot water production in Hong Kong," Appl. Energy, vol. 87, no. 9, pp. 2818-2825, 2010.

[65] T. Bergene and O. Martin Lovvik, "MODEL CALCULATIONS ON A FLAT-PLATE SOLAR HEAT COLLECTOR WITH INTEGRATED SOLAR CELLS," Sol. Energy, vol. 55, no. 6, pp. 453-462, 1995.

[66] M. Wolf, "Performance analyses of combined heating and photovoltaic power systems for residences," Energy Convers., vol. 16, no. 1-2, pp. 79-90, 1976.

[67] P. Raghuraman, "Analytical Predictions of Liquid and Air Photovoltaic/Thermal, FlatPlate Collector Performance," J. Sol. Energy Eng., vol. 103, no. 4, pp. 291-298, 1981.

[68] B. Sandnes and J. Rekstad, "A PHOTOVOLTAIC / THERMAL ( PV / T ) COLLECTOR WITH A POLYMER ABSORBER PLATE . EXPERIMENTAL STUDY AND ANALYTICAL MODEL †," Sol. Energy, vol. 72, no. 1, pp. 63-73, 2002.

[69] Y. Tripanagnostopoulos, T. H. Nousia, M. Souliotis, and P. Yianoulis, "HYBRID PHOTOVOLTAIC / THERMAL SOLAR SYSTEMS," Sol. Energy, vol. 72, no. 3, pp. 217-234, 2002.

[70] T. T. Chow, "Performance analysis of photovoltaic-thermal collector by explicit dynamic model," Sol. Energy, vol. 75, pp. 143-152, 2003.

[71] W. He, T. Chow, J. Ji, J. Lu, and G. Pei, "APPLIED Hybrid photovoltaic and thermal solar-collector designed for natural circulation of water," Appl. Energy, vol. 83, pp. 199-210, 2006.

[72] P. G. Charalambous, G. G. Maidment, S. A. Kalogirou, and K. Yiakoumetti, “Photovoltaic thermal ( PV / T ) collectors : A review," Appl. Therm. Eng., vol. 27, pp. 
275-286, 2007.

[73] T. T. Chow, G. Pei, K. F. Fong, Z. Lin, A. L. S. Chan, and J. Ji, “Energy and exergy analysis of photovoltaic - thermal collector with and without glass cover," Appl. Energy, vol. 86, no. 3, pp. 310-316, 2009.

[74] M. Herrando and C. N. Markides, "Hybrid PV and solar-thermal systems for domestic heat and power provision in the UK : Techno-economic considerations," Appl. Energy, vol. 161, pp. 512-532, 2016.

[75] H. D. Fu, G. Pei, J. Ji, H. Long, T. Zhang, and T. T. Chow, "Experimental study of a photovoltaic solar-assisted heat-pump/heat-pipe system," Appl. Therm. Eng., vol. 40, pp. 343-350, 2012.

[76] X. Zhang, X. Zhao, J. Xu, and X. Yu, "Characterization of a solar photovoltaic/loopheat-pipe heat pump water heating system," Appl. Energy, vol. 102, pp. 1229-1245, 2013.

[77] R. Thygesen and B. Karlsson, "Economic and energy analysis of three solar assisted heat pump systems in near zero energy buildings," Energy Build., vol. 66, pp. 77-87, 2013.

[78] R. Thygesen and B. Karlsson, "Simulation and analysis of a solar assisted heat pump system with two different storage types for high levels of PV electricity selfconsumption," Sol. Energy, vol. 103, pp. 19-27, 2014.

[79] A. Hazi and G. Hazi, "Comparative study of indirect photovoltaic thermal solarassisted heat pump systems for industrial applications," Appl. Therm. Eng., vol. 70, no. 1, pp. 90-99, 2014.

[80] N. Gunasekar, M. Mohanraj, and V. Velmurugan, "Artificial neural network modeling of a photovoltaic-thermal evaporator of solar assisted heat pumps," Energy, vol. 93, pp. 908-922, 2015.

[81] M. Qu, J. Chen, L. Nie, F. Li, Q. Yu, and T. Wang, "Experimental study on the operating characteristics of a novel photovoltaic/thermal integrated dual-source heat pump water heating system," Appl. Therm. Eng., vol. 94, no. 17-18, pp. 819-826, 2016. 
[82] C. Xi, L. Lin, and Y. Hongxing, "Long term operation of a solar assisted ground coupled heat pump system for space heating and domestic hot water," Energy Build., vol. 43, no. 8, pp. 1835-1844, 2011.

[83] A. Çağlar and C. Yamali, "Performance analysis of a solar-assisted heat pump with an evacuated tubular collector for domestic heating," Energy Build., vol. 54, pp. 22-28, 2012.

[84] T. T. Chow, Y. Bai, K. F. Fong, and Z. Lin, "Analysis of a solar assisted heat pump system for indoor swimming pool water and space heating," Appl. Energy, vol. 100, pp. 309-317, 2012.

[85] R. Yumrutaş and M. Ünsal, "Energy analysis and modeling of a solar assisted house heating system with a heat pump and an underground energy storage tank," Sol. Energy, vol. 86, no. 3, pp. 983-993, 2012.

[86] E. Wang, A. S. Fung, C. Qi, and W. H. Leong, "Performance prediction of a hybrid solar ground-source heat pump system," Energy Build., vol. 47, pp. 600-611, 2012.

[87] A. Moreno-Rodriguez, N. Garcia-Hernando, A. González-Gil, and M. Izquierdo, "Experimental validation of a theoretical model for a direct-expansion solar-assisted heat pump applied to heating," Energy, vol. 60, pp. 242-253, 2013.

[88] F. M. Rad, A. S. Fung, and W. H. Leong, "Feasibility of combined solar thermal and ground source heat pump systems in cold climate, Canada," Energy Build., vol. 61, pp. 224-232, 2013.

[89] L. Dai, S. Li, L. DuanMu, X. Li, Y. Shang, and M. Dong, "Experimental performance analysis of a solar assisted ground source heat pump system under different heating operation modes," Appl. Therm. Eng., vol. 75, pp. 325-333, 2015.

[90] G. Emmi, A. Zarrella, M. De Carli, and A. Galgaro, "An analysis of solar assisted ground source heat pumps in cold climates," Energy Convers. Manag., vol. 106, pp. 660-675, 2015.

[91] W. Köppen, "Versuch einer Klassifikation der Klimate, vorzugsweise nach ihren Beziehungen zur Pflanzenwelt," Geogr Zeitschr, vol. 6, pp. 593-611, 1900. 
[92] R. Geiger, "Überarbeitete Neuausgabe von Geiger, R.: Köppen- Geiger/Klima der Erde," Klett-Perthes, Gotha, 1961.

[93] ASHRAE, “STANDARD 90.1-2013 -- ENERGY STANDARD FOR BUILDINGS EXCEPT LOWRISE RESIDENTIAL BUILDINGS," Atlanta, GA, USA, 2013.

[94] J. Zhou et al., "Experimental investigation of a solar driven direct-expansion heat pump system employing the novel PV/micro-channels-evaporator modules," Appl. Energy, vol. 178, pp. 484-495, 2016.

[95] F. Calise, M. Dentice d'Accadia, R. D. Figaj, and L. Vanoli, “A novel solar-assisted heat pump driven by photovoltaic/thermal collectors: Dynamic simulation and thermoeconomic optimization," Energy, vol. 95, pp. 346-366, 2016.

[96] M. A. Obalanlege, Y. Mahmoudi, R. Douglas, E. Ebrahimnia-bajestan, J. Davidson, and D. Bailie, "Performance assessment of a hybrid photovoltaic-thermal and heat pump system for solar heating and electricity Number of Transfer Units," Renew. Energy, vol. 148, pp. 558-572, 2020.

[97] G. Emmi, A. Zarrella, and M. De Carli, "A heat pump coupled with photovoltaic thermal hybrid solar collectors: A case study of a multi-source energy system," Energy Convers. Manag., vol. 151, no. September, pp. 386-399, 2017.

[98] H. Li and Y. Sun, "Operational performance study on a photovoltaic loop heat pipe/solar assisted heat pump water heating system," Energy Build., vol. 158, pp. 861-872, 2018.

[99] E. I. Sakellariou, A. J. Wright, P. Axaopoulos, and M. A. Oyinlola, "PVT based solar assisted ground source heat pump system : Modelling approach and sensitivity analyses," Sol. Energy, vol. 193, pp. 37-50, 2019.

[100] A. Del, A. Martínez-gracia, A. A. Bayod-rújula, and M. Ca, "Performance analysis and experimental validation of a solar-assisted heat pump fed by photovoltaic-thermal collectors," Energy, vol. 169, pp. 1214-1223, 2019.

[101] E. Bellos and C. Tzivanidis, "Multi-objective optimization of a solar assisted heat pump-driven by hybrid PV," Appl. Therm. Eng., vol. 149, no. April 2018, pp. 528-535, 
2019.

[102] J. Zhou, X. Zhao, Y. Yuan, J. Li, M. Yu, and Y. Fan, “Operational performance of a novel heat pump coupled with mini-channel PV / T and thermal panel in low solar radiation," Energy Built Environ., vol. 1, pp. 50-59, 2020.

[103] N. Shao, L. Ma, and J. Zhang, "Experimental investigation on the performance of direct-expansion roof-PV / T heat pump system," Energy, vol. 195, 2020.

[104] J. Yao, H. Xu, Y. Dai, and M. Huang, "Performance analysis of solar assisted heat pump coupled with build-in PCM heat storage based on PV / T panel Nomenclature :," Sol. Energy, vol. 197, pp. 279-291, 2020.

[105] G. Wang, Y. Zhao, Z. Quan, and J. Tong, "Application of a multi-function solar-heat pump system in residential buildings," Appl. Therm. Eng., vol. 130, pp. 922-937, 2018.

[106] J. Cai, Z. Li, J. Ji, and F. Zhou, "Performance analysis of a novel air source hybrid solar assisted heat pump," Renew. Energy, vol. 139, pp. 1133-1145, 2019.

[107] W. Youssef, Y. T. Ge, and S. A. Tassou, "Effects of latent heat storage and controls on stability and performance of a solar assisted heat pump system for domestic hot water production," Sol. Energy, vol. 150, pp. 394-407, 2017.

[108] M. T. Plytaria, E. Bellos, C. Tzivanidis, and K. A. Antonopoulos, "Financial and energetic evaluation of solar-assisted heat pump under $\mathrm{fl}$ oor heating systems with phase change materials," Appl. Therm. Eng., vol. 149, pp. 548-564, 2019.

[109] C. Kutlu, Y. Zhang, T. Elmer, Y. Su, and S. Riffat, "A simulation study on performance improvement of solar assisted heat pump hot water system by novel controllable crystallization of supercooled PCMs," Renew. Energy, vol. 152, pp. 601-612, 2020.

[110] G. Besagni, L. Croci, R. Nesa, and L. Molinaroli, "Field study of a novel solar-assisted dual-source multifunctional heat pump," Renew. Energy, vol. 132, pp. 1185-1215, 2020.

[111] A. Shirazi, S. Pintaldi, S. D. White, G. L. Morrison, G. Rosengarten, and R. A. Taylor, "Solar-assisted absorption air-conditioning systems in buildings: Control strategies and operational modes," Appl. Therm. Eng., vol. 92, pp. 246-260, 2016. 
[112] E. Bellos, C. Tzivanidis, and N. Nikolaou, "Investigation and optimization of a solar assisted heat pump driven by nanofluid-based hybrid PV," Energy Convers. Manag., vol. 198, pp. 111831, 2019.

[113] C. Fraga, P. Hollmuller, F. Mermoud, and B. Lachal, "Solar assisted heat pump system for multifamily buildings: Towards a seasonal performance factor of 5 ? Numerical sensitivity analysis based on a monitored case study," Sol. Energy, vol. 146, pp. 543$564,2017$.

[114] F. Scarpa and L. A. Tagliafico, "Exploitation of humid air latent heat by means of solar assisted heat pumps operating below the dew point," Appl. Therm. Eng., vol. 100, pp. 820-828, 2016.

[115] S. H. Razavi, R. Ahmadi, and A. Zahedi, "Modeling, simulation and dynamic control of solar assisted ground source heat pump to provide heating load and DHW," Appl. Therm. Eng., vol. 129, pp. 127-144, 2018.

[116] H. Weeratunge, G. Narsilio, J. de Hoog, S. Dunstall, and S. Halgamuge, "Model predictive control for a solar assisted ground source heat pump system," Energy, vol. 152, pp. 974-984, 2018.

[117] J. P. Fine, H. V. Nguyen, J. Friedman, W. H. Leong, and S. B. Dworkin, "A simplified ground thermal response model for analyzing solar-assisted ground source heat pump systems," Energy Convers. Manag., vol. 165, no. January, pp. 276-290, 2018.

[118] E. Mohamed, S. Riffat, S. Omer, and R. Zeinelabdein, “A comprehensive investigation of using mutual air and water heating in multi-functional DX-SAMHP for moderate cold climate," Renew. Energy, vol. 130, pp. 582-600, 2019.

[119] W. Huang, T. Zhang, J. Ji, and N. Xu, "Energy \& Buildings Numerical study and experimental validation of a direct-expansion solar-assisted heat pump for space heating under frosting conditions," Energy Build., vol. 185, pp. 224-238, 2019.

[120] M. Mohanraj, Y. Belyayev, S. Jayaraj, A. Kaltayev, "Research and developments on solar assisted compression heat pump systems - A comprehensive review (Part A: Modelling and modifications)" Renewable and Sustainable Energy Reviews, vol. 83, pp 90-123, 2018. 
[121] M. Mohanraj, Y. Belyayev, S. Jayaraj, A. Kaltayev, "Research and developments on solar assisted compression heat pump systems - A comprehensive review (Part-B: Applications)" Renewable and Sustainable Energy Reviews, vol. 83, pp 124-155, 2018.

[122] M. Mohanraj, S. Jayaraj, C. Muraleedharan, "Applications of artificial neural networks for refrigeration, air-conditioning and heat pump systems-A review" Renewable and Sustainable Energy Reviews, vol. 16:2, pp 1340-1358, 2012.

[123] G. Shi, L. Aye, D. Li, X. Du, "Recent advances in direct expansion solar assisted heat pump systems: A review" Renewable and Sustainable Energy Reviews, vol. 109, pp 349-366, 2019.

[124] F. Razi and I. Dincer, "A new solar combined cycle integrated with heat pump system," Appl. Thermal Eng., vol. 173, pp. 114784, 2020. 